\title{
Structural changes in cow, goat, and sheep skim milk during dynamic in vitro gastric digestion
}

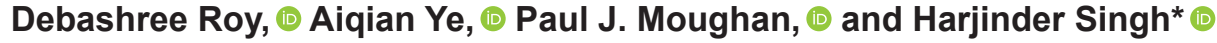 \\ Riddet Institute, Massey University, Private Bag 11 222, Palmerston North 4442, New Zealand
}

\begin{abstract}
Coagulation of milk in the stomach is the first crucial step in its digestion. Using a human gastric simulator, the dynamic gastric digestion of goat and sheep skim milk were compared with that of cow skim milk, focusing particularly on their physical characteristics. The gastric contents were analyzed for changes in dry matter and microstructure, and the extent of protein digestion. The study revealed that the skim milk from all species formed a curd within the first $15 \mathrm{~min}$ of gastric digestion, at which time the $\mathrm{pH}$ was $\sim 6.1$ to 6.3 . Compared with cow skim milk, the dry matter contents of the clots formed from goat and sheep skim milk were lower and higher, respectively, which was due to the differences in their total solids and protein contents. Microstructural analysis showed that, as digestion progressed, the clot structure became more cohesive, along with a decrease in moisture content, which in turn affected the breakdown and hydrolysis of caseins by pepsin; this phenomenon was similar for milk from all species. However, the extent of moisture retained in the sheep skim milk clot appeared to be lower than those of the cow and goat skim milk clots. In addition, the relative firmness of the sheep milk clot was higher than those of the cow and goat milk clots at the end of gastric digestion. The pattern of protein hydrolysis by pepsin was similar for the milk of all species, despite the differences in the proportions of different proteins. The study provided insight into the coagulation kinetics of goat and sheep skim milk under in vitro gastric digestion conditions.
\end{abstract}

Key words: non-cow milk, protein coagulation, structure, gastric digestion

\section{INTRODUCTION}

The traditional dairy industry, which is based mainly on cow milk, is becoming increasingly diversified with

Received April 24, 2020.

Accepted September 18, 2020.

*Corresponding author: H.Singh@massey.ac.nz goat and sheep milk; this is primarily due to consumer perceptions about the health benefits of these non-cow milks. Goat and sheep milk are potential options for the development of various dairy products (Claeys et al., 2014; Crowley et al., 2017). Goat and sheep milks are known to differ from cow milk in composition, physicochemical properties, and characteristics of the casein micelles as well as fat globules (Haenlein, 1996; Park et al., 2007; Claeys et al., 2014).

Goat milk contains lower amounts of casein (especially lower $\alpha_{S_{1}}$-casein) and larger casein micelles than cow milk; these characteristics are considered to be responsible for the weak consistency of goat milk gels upon acid or enzymatic coagulation (Storry et al., 1983; Bell and Vlahopouloua, 1995; Ould Eleya et al., 1998). By contrast, higher amounts of caseins and minerals in sheep milk are considered to be responsible for its stronger acid or rennet gel than goat or cow milk (Storry et al., 1983; Ould Eleya et al., 1998; Domagała, 2009). Such observations have led to a widespread perception that goat milk may form soft or loose curd in the human stomach, leading to easier digestion compared with the firm curd formed by cow milk (Jenness, 1980; El-Agamy, 2007; Maathuis et al., 2017). However, little is known about the coagulation characteristics of goat and sheep milk in the human stomach. To date, no direct comparative studies on the coagulation behavior of cow, goat, and sheep milk in the stomach have been reported, although a few in vitro studies have reported the comparative proteolysis profiles of proteins in these milks. For instance, Jasińska (1995) observed that the in vitro peptic as well as tryptic hydrolysis rates of micellar caseins from goat skim milk were higher than those of cow skim milk (based on protein content). The higher proteolysis rate of goat milk was attributed to the smaller size of its micellar aggregates (or complexes) and the presence of a higher proportion of $\beta$-casein in its micellar structures compared with cow milk. Similarly, Hodgkinson et al. (2018) reported that lower proportions of caseins remained undigested in whole goat milk than in whole cow milk during the first 60 min of static in vitro gastric digestion at $\mathrm{pH} 3.0$ (based on SDS-PAGE analysis); they speculated that 
this could be due to the fragile nature of the coagulum formed by goat milk compared with cow milk.

All of the previous studies on the milk of different species were carried out using static in vitro digestion models. It is now well accepted that, to understand the physicochemical modification as well as digestive dynamics of a complex structured fluid such as milk, the use of dynamic gastric digestion models is essential (Ye et al., 2017, 2019; Mulet-Cabero et al., 2019). Several recent studies have focused on simulating and understanding the structural changes that occur in the milk matrix during dynamic in vitro gastric digestion (Ye et al., 2016a, 2019; Mulet-Cabero et al., 2019); it is clear that the coagulation of milk during the gastric phase is a key factor in influencing the rate of delivery of macronutrients to the small intestine. Our previous study on the gastric digestion of cow skim milk (Ye et al., 2016b) using a human gastric simulator (HGS) revealed that the casein micelles formed a structured clot whereas the whey proteins remained soluble under the simulated dynamic gastric digestion conditions, leading to a slower emptying of caseins and a faster emptying of whey proteins from the stomach; these results were similar to those obtained by Mahé et al. (1996) and Boirie et al. (1997) in their clinical studies. The HGS is widely recognized as a dynamic stomach model that efficiently simulates the physiologically relevant mechanical forces that develop in vivo (Ferrua and Singh, 2015; Mulet-Cabero et al., 2020).

All the previous dynamic in vitro gastric digestion studies have been based on cow milk. To date, no dynamic gastric digestion studies have been reported for goat milk and sheep milk. We hypothesize that, because the milk from cows, goats, and sheep vary in composition and physicochemical properties, differences may appear in the curd (or clot) formation and disintegration in the stomach. Therefore, in this study, we investigated for the first time the dynamic comparative coagulation as well as nutrient release behaviors of cow, goat, and sheep skim milk using the HGS.

\section{MATERIALS AND METHODS}

Pooled cow (Jan-May 2018), goat (Jan-May 2018), and sheep (Jan-April 2019) raw whole milk were obtained under chilled conditions from the Massey University No. 4 Dairy Farm (Palmerston North, New Zealand), Dairy Goat Co-operative (Hamilton, New Zealand), and Neer Enterprises Limited (Carterton, New Zealand), respectively. The milking breeds for cow (Bos taurus), goat (Capra aegagrus hircus), and sheep (Ovis aries) were predominantly Friesian $\times$ Jersey, Saanen, and East Friesian, respectively.
Pepsin from porcine gastric mucosa (EC 3.4.23.1; catalog no. P7000, Sigma Aldrich Co. LLC, St. Louis, MO) had an average enzymatic activity of $325 \pm 13$ units/mg of solids, measured as outlined in the supplemental material of the harmonized INFOGEST protocol (Minekus et al., 2014). All other chemicals were also obtained from Sigma Aldrich, unless otherwise specified. All solutions were prepared from analytical-grade chemicals. Milli-Q water (water purified by treatment with a Milli-Q apparatus; Mill-Q Synthesis, Millipore Corp., Molsheim, France) was used for the preparation of all solutions.

\section{Milk Processing and Storage}

Raw skim milk was prepared by low-speed centrifugation of raw whole milk at $3,500 \times g$ for 20 min at $4^{\circ} \mathrm{C}$ in a Thermo Fisher Scientific Multifuge Heraeus 3SR+ Centrifuge (Thermo Electron LED GmbH, Osterode, Germany) and then decanted carefully by removing the fat layer. For pasteurized skim milk, pasteurized whole milk $\left(72^{\circ} \mathrm{C}, 15 \mathrm{~s}\right)$ was cooled to $4^{\circ} \mathrm{C}$ and then separated into skim milk by low-speed centrifugation as previously stated. To avoid microbial growth, $0.02 \%$ (wt/ wt) sodium azide (Merck KGaA, Darmstadt, Germany) was added to all samples. For all the analyses, the skim milk samples were stored in a cold room at $4^{\circ} \mathrm{C}$ until further use.

\section{Chemical Composition}

Total solids, fat, total protein (total nitrogen $\times 6.38$ ), and ash were determined using air oven-drying method 990.19, Mojonnier method 989.05, Dumas method 968.06, and gravimetric method 945.46, respectively (AOAC, 2005). The available carbohydrate content was determined by the difference method: $100-$ (moisture + total protein + fat + ash). The total calcium and inorganic phosphorus contents of the samples were analyzed on an RX Daytona Plus analyzer (Randox Laboratories, Crumlin, UK) using Randox reagents CA 8309 and PH 8328, respectively (Li et al., 2019).

\section{Determination of Casein Micelle Size}

The mean hydrodynamic diameter (nm) - that is, the Z-average diameter (an intensity-based calculated value) of the casein micelles - was measured by a dynamic light-scattering technique using a Zetasizer Nano ZS (Malvern Instruments Ltd., Malvern, UK), as described by Roy et al. (2020). The raw and pasteurized skim milk samples were diluted 100 times with a calcium im- 
idazole buffer solution ( $\mathrm{pH}$ 6.7) containing $20 \mathrm{mM}$ imidazole, $5 \mathrm{mM} \mathrm{CaCl}_{2}$, and $30 \mathrm{mM} \mathrm{NaCl}$ (Anema, 1997; Anema and Li, 2003a,b). The diluted milk samples were filtered using a $0.45-\mu \mathrm{m}$ syringe filter to remove large particles just before analysis. The samples were equilibrated for about $120 \mathrm{~s}$ and then measured at $25^{\circ} \mathrm{C}$ in a particle sizing cell using back-scattering technology at a detection angle of $173^{\circ}$. A general-purpose (normal resolution) analysis model was used. The calcium imidazole buffer was used as a common diluent for easier comparative analysis of all skim milk samples.

\section{In Vitro Gastric Digestion}

An HGS (Kong and Singh, 2010; Ferrua and Singh, 2015) was used for running simulated gastric digestion experiments with some modifications for a liquid food such as milk. The oral digestion fluid phase, normally containing amylase, was not included, as milk contains no starch (Minekus et al., 2014). Simulated gastric fluid (SGF, pH 7) was prepared according to the salt composition suggested in Minekus et al. (2014), but the $\mathrm{pH}$ was different. The ratio of total milk to total SGF was considered to be 1:1 for a liquid food diet, meaning that, in total, $200 \mathrm{~mL}$ of SGF was gradually added during the simulated gastric digestion of $200 \mathrm{~g}$ of milk (Wisén and Johansson, 1992; Minekus et al., 2014). The $200 \mathrm{~mL}$ of SGF was divided into 2 solutions: solution A, with $176 \mathrm{~mL}$ of SGF (inclusive of the amount of $6 \mathrm{M} \mathrm{HCl}$ needed to lower the $\mathrm{pH}$ of the different skim milks to $\mathrm{pH} 2$ in $4 \mathrm{~h}$ ); and solution B, with $24 \mathrm{~mL}$ of SGF ( $\mathrm{pH} 7$ ), which was used to make the pepsin solution. Thus, the combined $\mathrm{pH}$ of solution $\mathrm{A}+$ solution $\mathrm{B}$ was $1.40 \pm 0.10$, to achieve a gradual decrease in $\mathrm{pH}$ of the different milks to 2 over a period of $240 \mathrm{~min}(4 \mathrm{~h})$ of digestion. A separate batch of 25 $\mathrm{mL}$ of $\mathrm{SGF}$ at $\mathrm{pH} 2$ was prepared; this was added to the HGS at the beginning of the gastric digestion of all milk samples to simulate the fasting residual volume of the stomach (Maltby et al., 1986; Kong and Singh, 2008; Grimm et al., 2018). The amount of pepsin used for the raw cow skim milk was based on $2000 \mathrm{U} / \mathrm{mL}$ of the final digestion mixture (Minekus et al., 2014). The first batch of the cow skim milk sample had a protein concentration of $4.48 \%$ (g/100 g of milk), which meant that the overall pepsin-to-protein ratio was $94.25 \mathrm{U} /$ mg of cow skim milk protein. On this basis, the amount of pepsin used for all batches of cow, goat, and sheep skim milk was $94.25 \mathrm{U} / \mathrm{mg}$ of milk protein to achieve an overall equal pepsin-to-protein ratio (theoretical) for obtaining comparative protein digestion profiles.

The HGS was pre-warmed and maintained at $37 \pm$ $0.5^{\circ} \mathrm{C}$ throughout the experiment using a heater and a thermostat. A 200 -g pre-warmed milk sample at $\sim 37^{\circ} \mathrm{C}$ was added to the HGS and was allowed to mix for 1 min with the fasting residual volume $(25 \mathrm{~mL}$ of prewarmed SGF, pH 2). Then, $200 \mathrm{~mL}$ of SGF [176 mL of $\mathrm{SGF}$ (with $\mathrm{HCl}$ ) at $0.73 \mathrm{~mL} / \mathrm{min}$, and $24 \mathrm{~mL}$ of pepsin solution at $0.10 \mathrm{~mL} / \mathrm{min}$ ] was added gradually to the HGS at $0.83 \mathrm{~mL} / \mathrm{min}$ during the $240 \mathrm{~min}$ of gastric digestion. Every 30 min (30, 60, 90, 120, 150, 180, 210, and $240 \mathrm{~min}$ ), the chyme was emptied out (emptied liquid chyme) from the bottom of the HGS after sieving through a sieve with 1-mm pore size, to mimic human gastric sieving, equaling a gastric emptying rate of $\sim 1.66 \mathrm{~mL} / \mathrm{min}$ (i.e., $\sim 50 \mathrm{~mL}$ every $30 \mathrm{~min}$ ). The emptying rate was theoretically calculated for emptying $200 \mathrm{~g}$ of milk $+200 \mathrm{~mL}$ of SGF, a total of $\sim 400 \mathrm{~mL}$ of gastric contents in $4 \mathrm{~h}=1.66 \mathrm{~mL} / \mathrm{min}$, although the emptied liquid chyme at 210 and 240 min was $<50 \mathrm{~mL}$ due to coagulation of a part of liquid milk (i.e., caseins) during gastric digestion experiments. The gastric digestion time of $4 \mathrm{~h}$ was selected for all the milks based on the consideration that the complete emptying of a milk protein-based meal from the stomach would take about 3 to 6 h (Chabance et al., 1998; Boutrou et al., 2013). For analysis of the clot samples at each time interval (including a 15-min gastric digestion sample), the total sample was removed from the HGS and filtered through a mesh with a pore size of $1.0-\mathrm{mm}$ diameter to obtain both the coagulated mass (curd or clot) and the liquid phase (liquid chyme) for further analysis. We added $\mathrm{NaOH}(10 N)$ to the liquid chyme samples to increase the $\mathrm{pH}$ to 8 , to inhibit pepsin activity, and the samples were immediately stored at $-20^{\circ} \mathrm{C}$ for further analysis. The coagulated phase at different digestion time points was broken down into smaller pieces, mixed using a spatula, diluted with $\sim 100 \mathrm{~mL}$ of Milli-Q water to raise the $\mathrm{pH}$ to $\sim 5.5$ to 6.5 , and then immediately frozen at $-80^{\circ} \mathrm{C}$ to reduce the pepsin activity. The $\mathrm{pH}$, wet and dry weights, microstructure, and texture were determined immediately on fresh samples after stopping the gastric digestion at different time intervals with minimal disturbance to the clot structure. Additional gastric digestion experiments were performed for the microstructure and texture analyses.

\section{pH Measurement}

The initial natural $\mathrm{pH}$ of the milk samples and the $\mathrm{pH}$ of the liquid chyme (or emptied liquid chyme) samples from the HGS at each time point were measured using a CyberScan pH $510 \mathrm{pH} / \mathrm{mV} /{ }^{\circ} \mathrm{C}$ meter (Eutech Instruments, Fisher, Malaysia). The $\mathrm{pH}$ of the coagulated phase was also measured, by inserting the $\mathrm{pH}$ probe inside the clots (close to the center). All referenced $\mathrm{pH}$ values correspond to the $\mathrm{pH}$ of the liquid chyme, unless specified otherwise. 


\section{Dry Weights of the Clots}

Representative samples $(\sim 1 \mathrm{~g}$ each $)$ of the fresh wet clots (after being manually broken with a spatula to obtain homogeneous mixtures) obtained at different time intervals were dried (along with the respective skim milk sample) at $105^{\circ} \mathrm{C}$ for $16 \mathrm{~h}$ in an air oven (Contherm Scientific Ltd., Hutt City, New Zealand), so that the dry weights could be determined.

\section{Protein Content of the Clots}

The total protein (total nitrogen $\times 6.38$ ) contents of the clots (freeze-dried) were determined using the Dumas method 968.06 (AOAC, 2005).

\section{Identification of Milk Proteins by SDS-PAGE}

Reducing SDS-PAGE was performed on the milk clots (freeze-dried and ground powder) as well as on the liquid chyme samples, as described by Ye et al. (2016b). The samples were treated with sample buffer to visualize the time-dependent hydrolysis of the proteins in the gastric chyme samples. Different amounts of freeze-dried clot powder and liquid were mixed with sample buffer, to achieve equal protein concentrations in all chyme samples from the different milk. The samples were then heated in a boiling water bath for 5 min, cooled to room temperature, and loaded onto gels previously prepared on a Mini-Protean II system (Bio-Rad Laboratories, Richmond, CA). Electrophoresis was carried out at a constant voltage of $200 \mathrm{mV}$ for approximately $1 \mathrm{~h}$ on the PowerPac Basic power supply unit (Bio-Rad Laboratories) until the bromophenol blue dye reached the bottom of the gel. After staining and destaining, the gels were scanned using a Bio-Rad Molecular Imager Gel Doc XR+ imaging system linked to Bio-Rad Image Lab software (Version 5.2.1).

\section{Confocal Scanning Laser Microscopy}

A Leica SP5 upright confocal microscope (Leica Lasertechnik GmbH, Heidelberg, Germany) at the Manawatu Microscopy and Imaging Centre (Massey University, Palmerston North, New Zealand) was used for high-resolution imaging of the microstructure of the clot samples at 15, 90, and 240 min of digestion. A procedure similar to that of Ye et al. (2017) was followed. A $1.0 \%$ (wt/vol) solution of Fast Green (dye content 90\%) in water was used to stain protein (helium-neon laser with an excitation line at $633 \mathrm{~nm}$ ). At different time points, the clot samples were collected, immediately cut into thin slices using a surgical blade, and stained with
Fast Green solution for $10 \mathrm{~min}$. The stained samples were then placed on double concave microscope slides (clear glass, ground edges, $26 \mathrm{~mm} \times 76 \mathrm{~mm}, 1.2-1.3$ mm thick; Sail, Sailing Medical-Lab Industries Co. Ltd., Suzhou, China), covered with coverslips, and examined with a $63 \times$ oil immersion objective (numerical aperture $=1.4$ ). Care was taken to avoid areas near the sides or close to the top of the microscope slide while imaging. Multiple fields were viewed, and typical micrographs are presented. The imaging was completed within 40 min of stopping the digestion at the respective times.

\section{Texture Analysis of the Clots}

The clots remaining at the end of digestion (i.e., after $240 \mathrm{~min}$ ) were observed immediately for texture using penetration tests. Physical examination of the clots revealed that their outside layer was relatively soft compared with their inner core. Thus, the analysis was conducted by penetrating the clot samples from outside at different locations, to obtain the overall force that was required to penetrate a particular clot sample. Another experiment was also conducted; the clot was cut into 2 halves, and the force required to penetrate into the different areas of the core inside the clot was measured. A TA-XT Plus texture analyzer (Stable Micro Systems, Surrey, UK) was fitted with a $5.0-\mathrm{kg}$ load cell and a 2.0-mm diameter lightweight stainless-steel flat probe. For each test, Exponent software (version 6.1.15.0, Stable Micro Systems) was used for the TA-XT Plus. The setup was calibrated for load weight and height before starting the measurement. The probe was moved downward until contact with the sample just above the surface was detected. The experiment was run, and the sample was penetrated to a specified depth of $5.0 \mathrm{~mm}$ at a constant speed of $2.0 \mathrm{~mm} / \mathrm{s}$. On completion of the downward stroke, the probe was moved up at the same speed to above the surface of the sample. The measurements were taken at room temperature (about $22^{\circ} \mathrm{C}$ ). The value of the maximum force $(\mathrm{N})$ was obtained from the force-time curve of each measurement.

\section{Statistical Analysis}

Experimental data were analyzed by running ANOVA tests using Minitab statistical software (version 18.1, Minitab Inc., State College, PA). The changes in $\mathrm{pH}$, wet and dry weights, moisture content, and protein were analyzed using 2-way ANOVA, with milk, digestion time, and their interaction (milk $\times$ time) as fixed effects. Another 2-way ANOVA was used to analyze the force required to penetrate the milk clots, with milk, clot section (outside and core), and their interaction 
Table 1. Chemical compositions of cow, goat, and sheep milk ${ }^{1}$

\begin{tabular}{lccc}
\hline Properties & $\begin{array}{c}\text { Cow } \\
\text { skim milk }\end{array}$ & $\begin{array}{c}\text { Goat } \\
\text { skim milk }\end{array}$ & $\begin{array}{c}\text { Sheep } \\
\text { skim milk }\end{array}$ \\
\hline DM (\%) & $10.31 \pm 0.30^{\mathrm{b}}$ & $8.66 \pm 0.16^{\mathrm{c}}$ & $12.03 \pm 0.31^{\mathrm{a}}$ \\
Protein (\%) & $4.63 \pm 0.22^{\mathrm{b}}$ & $3.38 \pm 0.07^{\mathrm{c}}$ & $6.22 \pm 0.36^{\mathrm{a}}$ \\
Fat (\%) & $0.13 \pm 0.01^{\mathrm{b}}$ & $0.20 \pm 0.04^{\mathrm{a}}$ & $0.19 \pm 0.02^{\mathrm{a}}$ \\
Carbohydrates (by difference, \%) & $4.70 \pm 0.06^{\mathrm{a}}$ & $4.21 \pm 0.05^{\mathrm{c}}$ & $4.50 \pm 0.07^{\mathrm{b}}$ \\
Ash (\%) & $0.85 \pm 0.02^{\mathrm{b}}$ & $0.87 \pm 0.01^{\mathrm{b}}$ & $0.96 \pm 0.03^{\mathrm{a}}$ \\
Calcium (mmol/L) & $37.70 \pm 1.31^{\mathrm{b}}$ & $27.42 \pm 1.52^{\mathrm{c}}$ & $44.42 \pm 3.39^{\mathrm{a}}$ \\
Inorganic phosphorus (mmol/L) & $31.89 \pm 0.95^{\mathrm{b}}$ & $30.18 \pm 2.59^{\mathrm{b}}$ & $40.78 \pm 0.17^{\mathrm{a}}$ \\
\hline
\end{tabular}

${ }^{\mathrm{a}-\mathrm{c}}$ Values within each row with different superscripts are significantly different $(P<0.05)$ according to 1 -way ANOVA.

${ }^{1}$ Values are reported as mean $\pm \mathrm{SD}$ of results from at least 2 different batches of milk.

$($ milk $\times$ section $)$ as fixed effects. If significant interaction effects were found, further analysis was conducted with Tukey pairwise comparison test. Chemical composition and casein micelle size of milk were analyzed by using 1-way ANOVA with Tukey test. The minimum level of statistical significance was $P<0.05$. Statistical analysis was carried out on results from at least 2 different batches of milk, and values (or data points) are expressed as mean \pm standard deviation.

\section{RESULTS AND DISCUSSION}

\section{Chemical Compositions of Different Skim Milks}

The chemical compositions of the cow, goat, and sheep skim milk are shown in Table 1. Sheep milk was significantly higher $(P<0.05)$ and goat milk significantly lower $(P<0.05)$ than cow milk in total solids, crude protein, and calcium contents. Sheep milk also had higher amounts of phosphorus compared with cow and goat milk, both of which had similar phosphorus contents. The interspecies differences in the nutrient compositions observed were consistent with those reported in previous studies (Barłowska et al., 2011; Stergiadis et al., 2019; Roy et al., 2020). Considerable variability in milk composition within and between species exist in the literature, which is expected to be due to the differences in region, breed, feed, milking interval, stage of lactation, and time of the year (Claeys et al., 2014).

\section{Casein Micelle Sizes of Different Skim Milks}

The Z-average diameter (nm) of the casein micelles (Table 2) of cow milk was significantly $(P<0.05)$ smaller $(\sim 157-158 \mathrm{~nm})$ than those of sheep milk $(\sim 195-198 \mathrm{~nm})$ and goat milk $(\sim 192-201 \mathrm{~nm})$, in agreement with the results of previous studies (Park et al., 2007; Nguyen et al., 2018). No significant differences $(P>0.05)$ in the average casein micelle sizes of the raw and pasteurized milk from the same species were observed (Table 2). A low degree of denaturation of the whey proteins under pasteurization $\left(72^{\circ} \mathrm{C}, 15 \mathrm{~s}\right)$ conditions (Guinee et al., 1998; Rynne et al., 2004) would have led to a smaller amount of complexation between the denatured whey proteins and the casein micelles (Anema and Li, 2003a,b; Kethireddipalli et al., 2011); this appeared to have no effect on the casein micelle size of the pasteurized milk compared with its raw milk counterpart.

\section{pH Changes During Gastric Digestion of Different Skim Milks}

The changes in the $\mathrm{pH}$ profiles of the liquid chyme in the HGS as a function of time are shown in Figure 1. The initial $\mathrm{pH}$ in the HGS represents the $\mathrm{pH}$ of the residual gastric fluid; that is, $\mathrm{pH} 2$ at 0 min. With the ingestion of milk, the $\mathrm{pH}$ was immediately increased to $\sim 6.7$ (at $2 \mathrm{~min}$ ). Then, with the continuous addition of $\mathrm{SGF}(+\mathrm{HCl})$ and pepsin solution, the $\mathrm{pH}$ of the

Table 2. Casein micelle sizes of raw and pasteurized cow, goat, and sheep milk (RCSM = raw cow skim milk; RGSM = raw goat skim milk; RSSM = raw sheep skim milk; PCSM = pasteurized cow skim milk; PGSM = pasteurized goat skim milk; PSSM $=$ pasteurized sheep skim milk $)^{1}$

\begin{tabular}{|c|c|c|c|c|c|c|}
\hline Casein micelle size & \multicolumn{2}{|c|}{ Cow } & \multicolumn{2}{|c|}{ Goat } & \multicolumn{2}{|c|}{ Sheep } \\
\hline Z-average diameter $(\mathrm{nm})$ & $158.0 \pm 3.5^{\mathrm{b}}$ & $156.6 \pm 2.5^{\mathrm{b}}$ & $192.0 \pm 5.1^{\mathrm{a}}$ & $200.9 \pm 9.6^{\mathrm{a}}$ & $198.0 \pm 2.8^{\mathrm{a}}$ & $195.3 \pm 3.0^{\mathrm{a}}$ \\
\hline
\end{tabular}

$\overline{\mathrm{a}, \mathrm{b}}$ Values within each row with different superscripts are significantly different $(P<0.05)$ according to 1-way ANOVA.

${ }^{1}$ Values are reported as mean $\pm \mathrm{SD}$ of results from at least 2 different batches of milk. 
liquid chyme in the HGS decreased gradually for all milk samples. Raw cow skim milk and raw goat skim milk had similar gradual decreases in $\mathrm{pH}$ with digestion time; the $\mathrm{pH}$ of the liquid chyme at the end of $4 \mathrm{~h}(240$ min) was $\sim 2.0$ for both milks. Raw sheep skim milk had a slightly higher buffering capacity than raw goat and cow skim milk, as indicated by the slower decrease in $\mathrm{pH}$, especially from $150 \mathrm{~min}$ onward $(P<0.05)$, and the $\mathrm{pH}$ of its liquid chyme at 240 min was $\sim 2.3$. This was possibly due to the higher protein and mineral (calcium and phosphorus) contents (Park, 1991; Salaün et al., 2005) of raw sheep skim milk compared with raw goat and cow skim milk. These results were consistent with those reported by Vithana (2012); they observed that the titrated buffering capacity of raw sheep whole milk was significantly higher than that of raw cow and goat whole milks, both of which had similar buffering capacities. Some small but statistically significant differences $(P<0.05)$ in the decrease in $\mathrm{pH}$ were observed for pasteurized cow, goat, and sheep skim milks compared with their raw milk counterparts, especially from 60 min onwards. The $\mathrm{pH}$ at the end of $240 \mathrm{~min}$ for all pasteurized skim milk was in the range $\sim 2.6$ to 2.8 . In contrast with the $\mathrm{pH}$ of the liquid chyme, the $\mathrm{pH}$ at the center of the clots from the different milks toward the end of digestion were higher, pH 4.0 to 5.0 (results not shown), indicating the higher buffering capacity of the aggregated (or coagulated) casein phase.

\section{Coagulation Behavior of Different Skim Milks}

The photographs of the clots and liquid chyme obtained during the gastric digestion of $200 \mathrm{~g}$ of raw and pasteurized skim milk at different times are shown in Supplemental Figures S1 and S2 (https://doi.org/10 $.3168 /$ jds.2020-18779).

The initial signs of milk coagulation were detected within the first 6 to 7 min of digestion for all milk (as visually observed), soon after which all milk separated into a clot and a liquid phase. Both the raw and the pasteurized skim milks from cows, goats, and sheep formed a clot (or curd) within the first 15 min of gastric digestion, at which time the $\mathrm{pH}$ of the liquid chyme was around $\mathrm{pH} 6.1$ to 6.3. Ye et al. (2016b) and Wang et al. (2018) have reported similar coagulation $\mathrm{pH}$ for the clots (or curds) formed from raw cow skim milk and reconstituted low-heat cow skim milk powder during dynamic gastric digestion. No other reports on the coagulation behaviors of goat and sheep milk during dynamic digestion are available.

The formation of the milk clot at around $\mathrm{pH} 6.0$ is primarily due to the action of pepsin on the $\kappa$-casein located at the surface of the casein micelles (Ye et al., 2016b). Pepsin has been shown to cause faster initial rate of hydrolysis for $\kappa$-casein than $\alpha_{S^{-}}$and $\beta$-caseins at pH 6.0 (Tam and Whitaker, 1972). Pepsin hydrolyzes the $\mathrm{Phe}_{105}-\mathrm{Met}_{106}$ bond of $\kappa$-casein but also has the ability to hydrolyze bonds with Trp, Tyr, Leu, or Val residues in milk proteins (Agudelo et al., 2004; Moschopoulou, 2011). At the start of the in vitro gastric digestion, the pepsin concentration in the HGS was low but sufficient to quickly hydrolyze $\kappa$-casein to para- $\kappa$-casein and glycomacropeptide, resulting in destabilization of the casein micelles and their aggregation at $\sim \mathrm{pH}$ 6.0. This phenomenon has been shown to occur in the milk from all species (Jollès, 1966; Miranda and Pelissier,

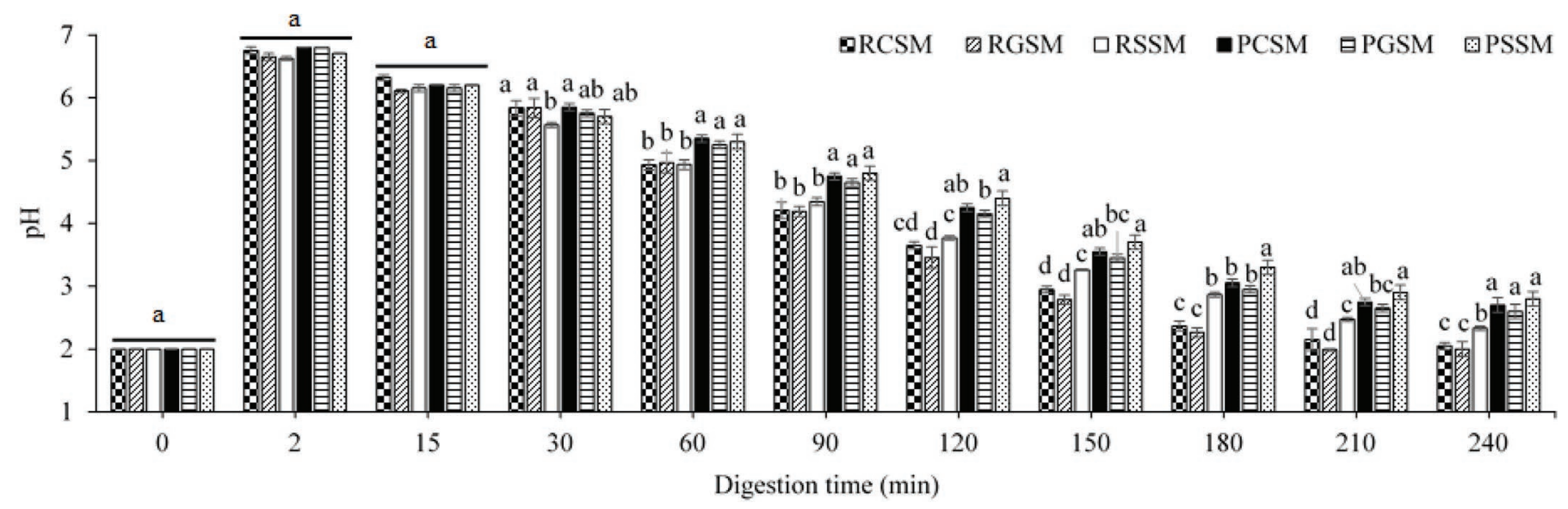

Figure 1. Changes in $\mathrm{pH}$ of skim milk during gastric digestion in the human gastric simulator. RCSM $=$ raw cow skim milk; RGSM $=$ raw goat skim milk; RSSM = raw sheep skim milk; PCSM = pasteurized cow skim milk; PGSM = pasteurized goat skim milk; PSSM = pasteurized sheep skim milk. Tukey's post hoc pairwise comparison test was performed when milk $\times$ digestion time interaction effect was significant $(P<$ 0.05). Different letters (a-d) above bars represent significant differences among milk samples at a given digestion time point $(P<0.05)$; differences within a particular milk sample across different digestion times are not represented. Each data point represents mean \pm SD of results from at least 2 different batches of milk. 
1983). The clot formed from raw milk is mainly due to coagulation of the caseins, whereas whey proteins do not play a functional role in raw milk clot formation (Ye et al., 2016b). Pasteurization $\left(72^{\circ} \mathrm{C}, 15 \mathrm{~s}\right)$ would be expected to cause a small degree of denaturation of whey proteins (Guinee et al., 1998; Rynne et al., 2004), but this did not appear to affect the initial clot formation, as both raw and pasteurized milk from all the species formed a clot within $15 \mathrm{~min}$ at $\mathrm{pH} \sim 6.1$ to 6.3 $(P>0.05$; Figure 1 and Supplemental Figures S1 and $\mathrm{S} 2)$. As digestion progressed (and the $\mathrm{pH}$ decreased), the concentration and activity of the pepsin in the HGS increased, which led to higher degrees of hydrolysis of all the caseins (Tam and Whitaker, 1972; Miranda and Pelissier, 1983).

Initially, when the clot was formed within the first 15 min (pH 6.1-6.3), it was loose and soft and had an open structure; however, as digestion progressed, the clot became smaller, more cohesive, and firmer. This was due to the combined action of pepsin, mechanical forces in the stomach, and the gradual decrease in $\mathrm{pH}$ due to stomach acid. The liquid chyme in the gastric phase was expected to consist mainly of water-soluble components of the milk, such as whey proteins, lactose, and minerals. The separated liquid phase at $<60 \mathrm{~min}$ of digestion was opaque and contained some fine aggregated particulate matter. This was due to the loose structure of the clot at the beginning of digestion leading to the loss of particulate matter from the clot. As digestion progressed and the $\mathrm{pH}$ reached near the isoelectric point of casein, $\mathrm{pH} 4.6$ ( $\sim 90 \mathrm{~min}$ onward), the clot became stronger and denser, leading to less transfer of aggregated casein particles to the liquid phase.
During the later stages of digestion, caseins would have mainly transferred as very fine dissolved particles (as well as peptides) from the outer surface of the clot to the liquid chyme.

\section{Dry Weights of the Clots}

The dry weights of the clots obtained during the gastric digestion of $200 \mathrm{~g}$ of different raw and pasteurized milks as a function of time are shown in Figure 2. In general, the dry weights of the raw and pasteurized milk clots from the different species progressively decreased with digestion time. The dry matter of the clots obtained from both raw and pasteurized milks during gastric digestion followed the order goat $<$ cow $<$ sheep $(P<0.05)$, and no significant difference $(P$ $>0.05)$ were detected in the dry weights of the clots formed from the raw and pasteurized milk within a species toward the end of digestion. The clots formed from goat milk had the lowest dry weights, and those formed from sheep milk had the highest dry weights, compared with those formed from cow milk. This was mainly dependent on the total protein (casein) as well as total solids contents of the milk.

The changes in the dried weight of the clot reflected the loss of matter, because of the removal (or squeezing out) of the entrapped liquid and loose curd particles from the clot (mainly during the early stages of digestion by the continuous mechanical contraction of the stomach) as well as hydrolysis of the coagulated proteins by pepsin (especially during the later stages of digestion). A similar phenomenon was reported by

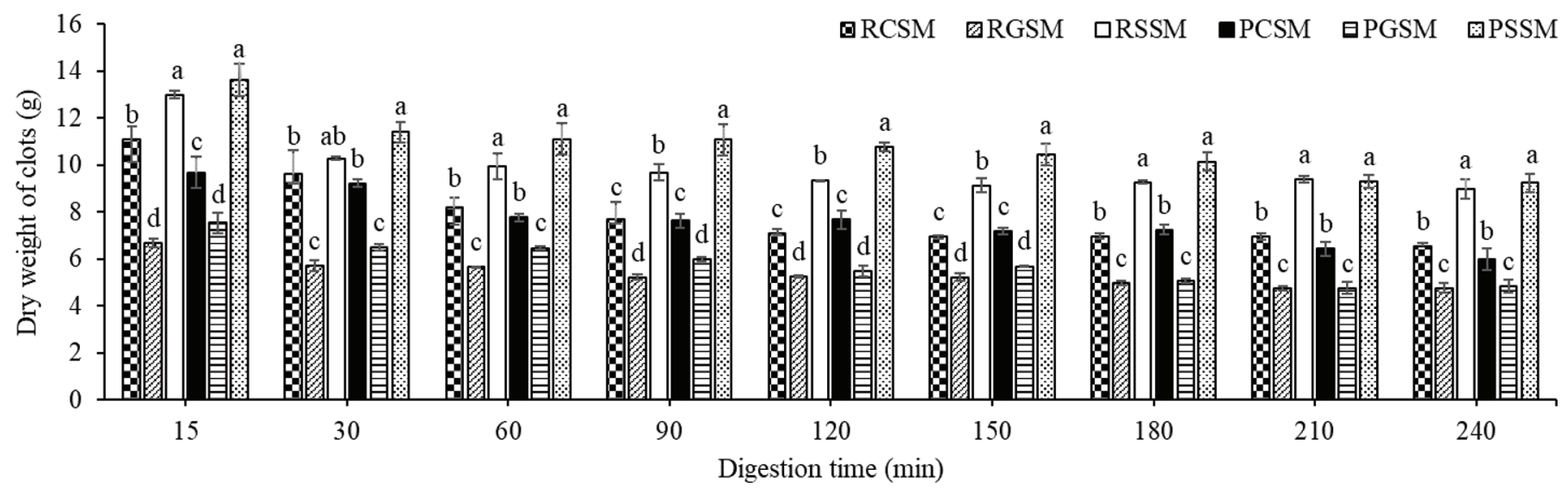

Figure 2. Changes in the dry weights of the clots during the gastric digestion of $200 \mathrm{~g}$ of skim milk in the human gastric simulator. RCSM = raw cow skim milk; RGSM = raw goat skim milk; RSSM = raw sheep skim milk; PCSM = pasteurized cow skim milk; PGSM = pasteurized goat skim milk; PSSM $=$ pasteurized sheep skim milk. Tukey's post hoc pairwise comparison test was performed when milk $\times$ digestion time interaction effect was significant $(P<0.05)$. Different letters $(\mathrm{a}-\mathrm{d})$ above bars represent significant differences among milk samples at a given digestion time point $(P<0.05)$; differences within a particular milk sample across different digestion times are not represented. Each data point represents mean $\pm \mathrm{SD}$ of results from at least 2 different batches of milk. 
Ye et al. (2016b) while studying the dynamic gastric digestion of raw cow skim milk using HGS; they also reported that both the stomach mechanical contraction and the pepsin activity play key roles in the gradual decrease of the dry matter content of the milk during gastric digestion.

\section{Moisture Content of the Clots}

Figure 3 shows the calculated overall moisture content ( $g$ of water retained per $g$ of dry matter) of the clots obtained at different digestion times (calculated based on the wet and dry weights of the clots obtained). It should be noted that the moisture content of the clots could be different between the outer layer and the inner core of the clot, as the outer layer of the clot was in direct contact with the surrounding liquid phase. Given the dynamic nature of the clot throughout digestion, it was difficult to segregate the moisture content of the outer and inner layers; therefore, the moisture content referred to here was based on the total dry matter of the clot.

The moisture contents of both the raw and the pasteurized skim milk clots from all 3 species decreased considerably with time after they had initially formed within $15 \mathrm{~min}$. The moisture content of the raw cow skim milk clots decreased gradually until $120 \mathrm{~min}$ of digestion, after which it remained fairly constant. Similarly, the moisture contents of the raw goat and sheep skim milk clots decreased rapidly until 90 and $60 \mathrm{~min}$ of digestion, respectively, after which the decrease was very slow (Figure 3). No significant differences were detectable between the moisture contents of the raw goat and cow skim milk clots at almost all digestion time points $(P>0.05)$. The raw sheep milk clots had considerably lower moisture content than the raw cow milk clots $(P<0.05)$; this was more evident during the initial stages of digestion, until 90 min of digestion. This lower initial moisture content of the raw sheep milk clots may be related to their lower initial wet weights (Supplemental Figure S3, https://doi.org/10.3168/jds .2020-18779), despite the higher total solids contents of sheep milk compared with cow milk (Table 1 and Figure 2). The pasteurized skim milk from all species had similar overall comparative patterns for moisture retained in the clots (Figure 3).

The calculated moisture content of the clots formed from both the raw and the pasteurized cow, goat, and sheep skim milks were in the ranges $\sim 3.2$ to $1.8,3.0$ to 1.7 , and 2.3 to $1.5 \mathrm{~g}$ of water/g of dried clot, respectively, for 15 to $240 \mathrm{~min}$ of digestion (Figure 3). These changes in moisture content of the raw cow skim milk clots (3.2-1.8 g of water/g of dried clot) were in line with the previous reported moisture content of clots (2.7-1.4 g of water/g of clot dry matter) during the gastric digestion of raw cow skim milk using an HGS (Ye et al., 2016b). The core hydration (excluding the $\kappa$-casein layer) of cow milk casein micelles is considered to be 2 to $3 \mathrm{~g}$ of water/g of protein (Dalgleish, 2014); the results obtained in our study for the cow skim milk clots were close to this range (although the clot moisture content obtained in our study may not a true representation of the hydration of the casein micelles due to the presence of other materials in the casein clot). No previous reports exist on the moisture content of the casein clots formed from goat milk and

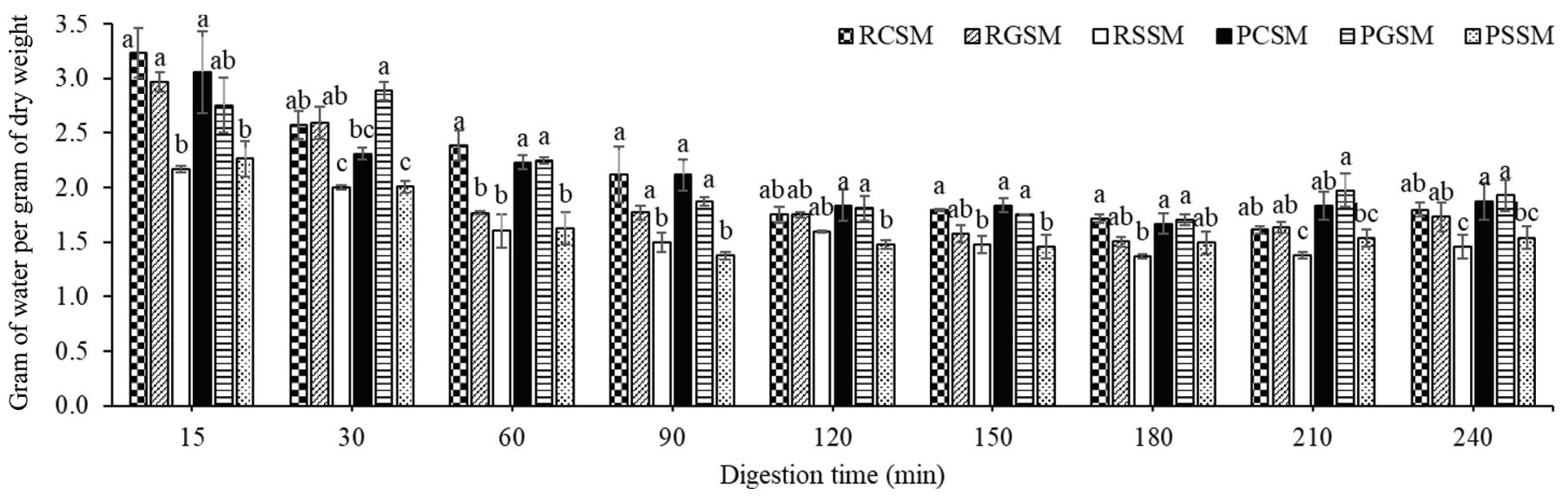

Figure 3. Changes in the moisture content of the raw and pasteurized skim milk clots collected during gastric digestion in the human gastric simulator. RCSM = raw cow skim milk; RGSM = raw goat skim milk; RSSM = raw sheep skim milk; PCSM = pasteurized cow skim milk; PGSM = pasteurized goat skim milk; PSSM = pasteurized sheep skim milk. Tukey's post hoc pairwise comparison test was performed when milk $\times$ digestion time interaction effect was significant $(P<0.05)$. Different letters $(\mathrm{a}-\mathrm{c})$ above bars represent significant differences among milk samples at a given digestion time point $(P<0.05)$; differences within a particular milk sample across different digestion times are not represented. Each data point represents mean $\pm \mathrm{SD}$ of results from at least 2 different batches of milk. 


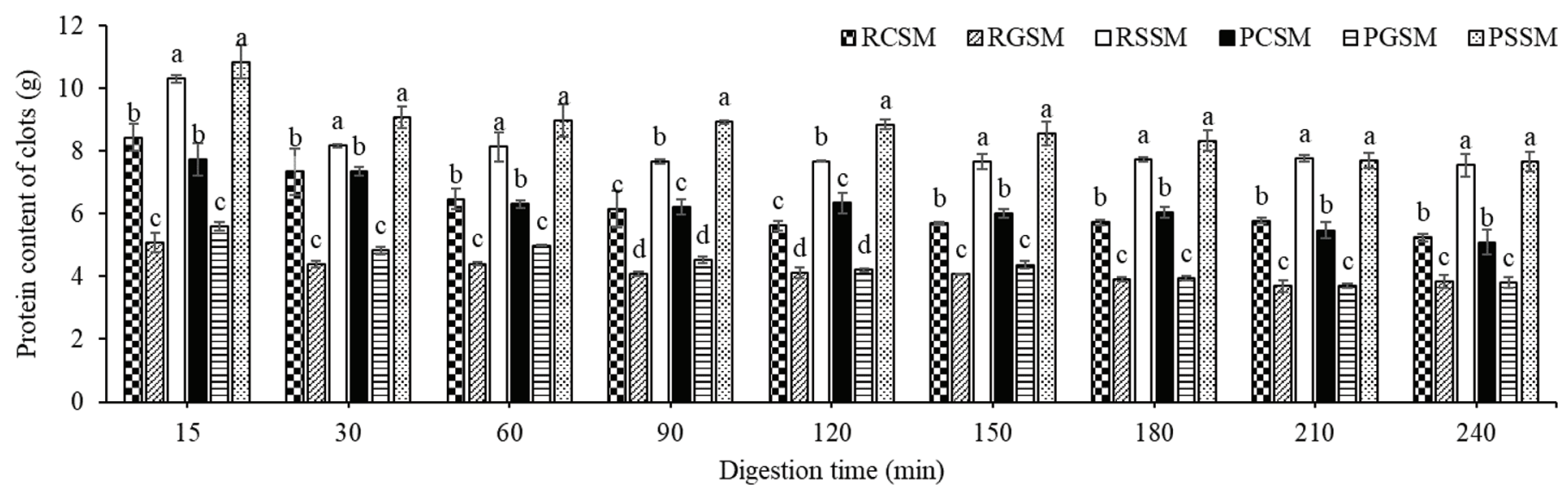

Figure 4. Changes in the protein content of the clots during the gastric digestion of $200 \mathrm{~g}$ of skim milk in the human gastric simulator. RCSM = raw cow skim milk; RGSM = raw goat skim milk; RSSM = raw sheep skim milk; PCSM = pasteurized cow skim milk; PGSM $=$ pasteurized goat skim milk; PSSM = pasteurized sheep skim milk. Tukey's post hoc pairwise comparison test was performed when milk $\times$ digestion time interaction effect was significant $(P<0.05)$. Different letters $(\mathrm{a}-\mathrm{d})$ above bars represent significant differences among milk samples at a given digestion time point $(P<0.05)$; differences within a particular milk sample across different digestion times are not represented. Each data point represents mean $\pm \mathrm{SD}$ of results from at least 2 different batches of milk.

sheep milk during gastric digestion. However, the hydration values of goat milk and sheep milk casein micelles have been reported to be lower (1.43-2.05 and 1.71-1.93 g of water/g of dry weight of casein micelles, respectively) than the hydration values for cow milk (Remeuf and Lenoir, 1986; Remeuf et al., 1989; Pellegrini et al., 1994). Sood et al. (1979) reported that the loss of micellar calcium from the skim milk casein micelles, when dialyzed against same skim milk sample containing EDTA, resulted in increased hydration (or swelling) of casein micelles. Thus, it is considered that the hydration level of the casein micelles is negatively correlated with mineralization of micelles (Remeuf and Lenoir, 1986); that is, when the mineralization of the casein micelle increases, the degree of hydration of casein micelle decreases. This is expected to be due to the decrease in the void spaces within the casein micelles that can be filled up with water, along with an increase in the extent of binding of the proteins in the casein micelle. Goat and sheep milk casein micelles are more mineralized (amount of colloidal calcium per $\mathrm{g}$ of casein) than cow milk casein micelles (Park, 2007; Park et al., 2007). Thus, the lower moisture content observed for sheep milk clots in our study could be due to the higher mineralization of its casein micelles. The sheep milk used in our study had higher total calcium and inorganic phosphorus than cow and goat milk.

\section{Protein Content of the Clots}

The quantities of protein retained (g/200 g of milk) in the dried clots from the different milks during di- gestion are shown in Figure 4. Skim milk clots were composed mainly of caseins with some minor amounts of entrapped water-soluble components such as lactose, whey proteins, and minerals. Thus, in general, the higher the protein (casein) content of the milk, the higher the amount of protein retained in the clot. The protein contents of the clots formed from the raw and pasteurized milk from the different species during digestion were in the following order: goat $<$ cow $<$ sheep $(P<0.05$; Figure 4$)$. The total protein content of the dried clots decreased gradually during digestion, with most of the decrease occurring during the initial stages of digestion for all the milk, up to $90 \mathrm{~min}$ (when $\mathrm{pH}$ was $\sim 4.2-4.8$ ). The decrease in protein content during this initial period was due mainly to the loss of fine casein particles and entrapped liquid (dissolved) whey proteins from the clots due to the less firm nature of the clot. After $90 \mathrm{~min}$ (as the $\mathrm{pH}$ dropped below the isoelectric point of casein, $\mathrm{pH} 4.6$ ), the clot became stronger and more cohesive. Thus, the decrease in the protein content of the clot after 90 min was slow and mainly due to the hydrolysis of caseins by pepsin.

As expected, the trend of the decrease in protein content of the clots (Figure 4) with digestion time was similar to that of the dry matter content of the clots (Figure 2), although the protein content generally remained lower than the dry matter content during gastric digestion. This difference may reflect the loss of entrapped lactose, whey proteins, and soluble salts from the clots, as well as dissolution and removal of micellar calcium phosphate from the casein clots because of a pH decrease to below 4.6 (Dalgleish and Law, 1989). 


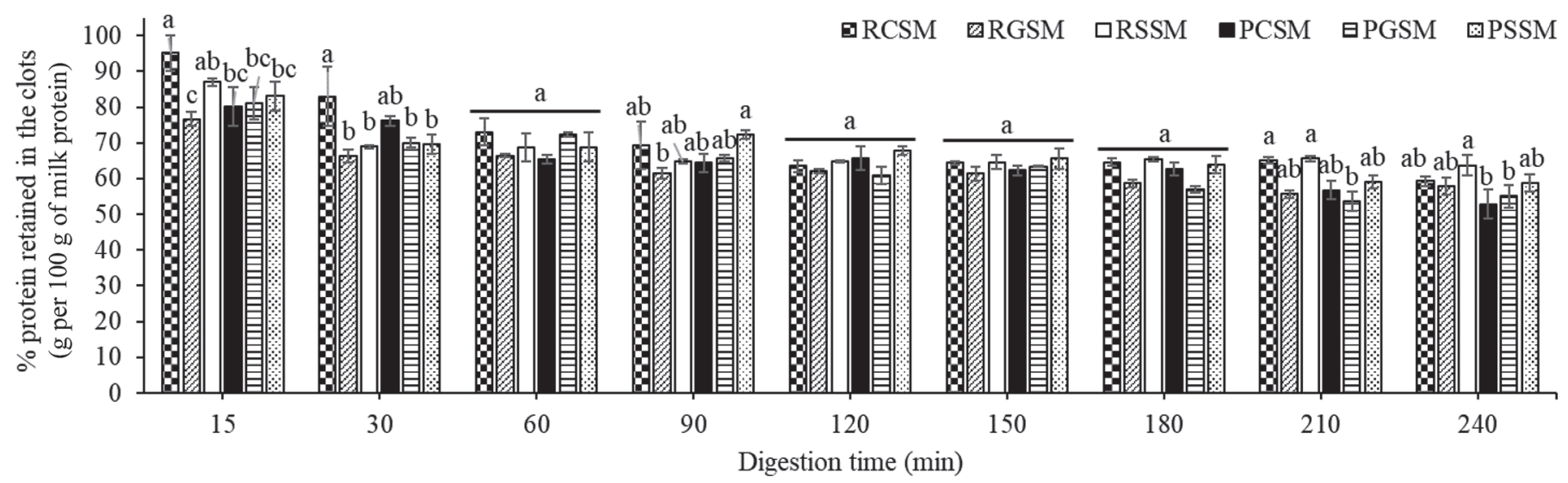

Figure 5. Changes in the percentage protein retained in the clots (expressed as $\mathrm{g} / 100 \mathrm{~g}$ of milk protein) during the gastric digestion of skim milk in the human gastric simulator. RCSM = raw cow skim milk; RGSM = raw goat skim milk; RSSM = raw sheep skim milk; PCSM $=$ pasteurized cow skim milk; PGSM = pasteurized goat skim milk; PSSM = pasteurized sheep skim milk. Tukey's post hoc pairwise comparison test was performed when milk $\times$ digestion time interaction effect was significant $(P<0.05)$. Different letters $(\mathrm{a}-\mathrm{c})$ above bars represent significant differences among milk samples at a given digestion time point $(P<0.05)$; differences within a particular milk sample across different digestion times are not represented. Each data point represents mean \pm SD of results from at least 2 different batches of milk.

The comparative percentage of protein retained (g/100 g of milk protein) in the dried clots from the different milks during digestion is shown in Figure 5. At the end of $240 \mathrm{~min}$ of digestion, approximately $59 \%, 58 \%$, and $64 \%$ of the milk protein remained in the raw cow, goat, and sheep skim milk clots, respectively. However, no significant differences $(P>0.05)$ occurred between the percentage of protein retained by the raw cow, goat, and sheep milk clots at $240 \mathrm{~min}$ (Figure 5). The percentage of protein retained in the pasteurized milk clots was slightly lower than that in their respective raw milk clots, but the differences were not significant $(P>0.05)$. For instance, approximately $53 \%, 55 \%$, and $59 \%$ of the protein remained in the pasteurized cow, goat, and sheep skim milk clots at 240 min, respectively.

Because the raw sheep skim milk had higher $\mathrm{pH}(P$ $<0.05)$ toward the later stages of gastric digestion than the raw goat and cow skim milks (150 min onward, Figure 1), another experiment was conducted (results not shown) to adjust the $\mathrm{pH}$ profile for sheep milk to achieve a $\mathrm{pH}$ of 2 with $\mathrm{SGF}(\mathrm{pH} \sim 1.3$, added extra $\mathrm{HCl}$ ). This was to explore whether sheep milk with the adjusted $\mathrm{pH}$ profile had a greater disintegration or hydrolysis of the clots. However, no significant difference was detectable in the dry matter and protein contents retained in the raw sheep milk clots with adjusted and unadjusted $\mathrm{pH}$ profiles. This indicated that the lower moisture content and the more tightly knitted clots formed by sheep skim milk, compared with the skim milks from the other species, might have been a factor in its lower disintegration rate.

\section{Protein Composition of the Clots}

During digestion in the gastric environment, the milk samples generated a clot and a liquid fraction. The protein compositions of the milk clots and the liquid chyme obtained at different digestion times were determined using SDS-PAGE under reducing conditions (Figures 6 and 7). Analysis of the raw cow skim milk clots (Figure $6, \mathrm{RCSM}$ ) showed that the intensity of the $\kappa$-casein band decreased markedly within 30 min of digestion, whereas the intensities of the other casein bands (especially $\alpha_{\mathrm{S1}^{-}}, \alpha_{\mathrm{S}^{-}}$, and $\beta$-caseins) at 30 min were much higher and remained fairly constant during further digestion. In addition, a $15-\mathrm{kDa}$ band (para- $\kappa$-casein band derived from the hydrolysis of $\kappa$-casein) appeared at 30 min of digestion, and the intensity of this band did not change with digestion time. A faint $\beta$-lactoglobulin band was also observed in all clots, which was possibly due to the entrapped stomach liquid in the pore spaces of the clots. Some other intense bands (such as at $\sim 20$, $16.5,12$, and $10 \mathrm{kDa}$ ) were also observed at $30 \mathrm{~min}$ of digestion; the intensities of these bands increased only slightly with digestion time. However, these bands also appeared to be present in the undigested cow milk, as indicated by their extremely faint intensities (Figure 6, RCSM). This means that, as the milk clotted, these bands concentrated in the clotted fraction of the milk, and their intensities increased with further enzymatic hydrolysis. Miranda and Pelissier (1983) observed the presence of $\gamma_{1}$-casein $(20.5 \mathrm{kDa}), \gamma_{2}$-casein, and $\gamma_{3}$-casein $(11.5 \mathrm{kDa})$ bands in raw cow skim milk and its chyme sediments in rats. $\gamma$-Casein is known to be a natural 

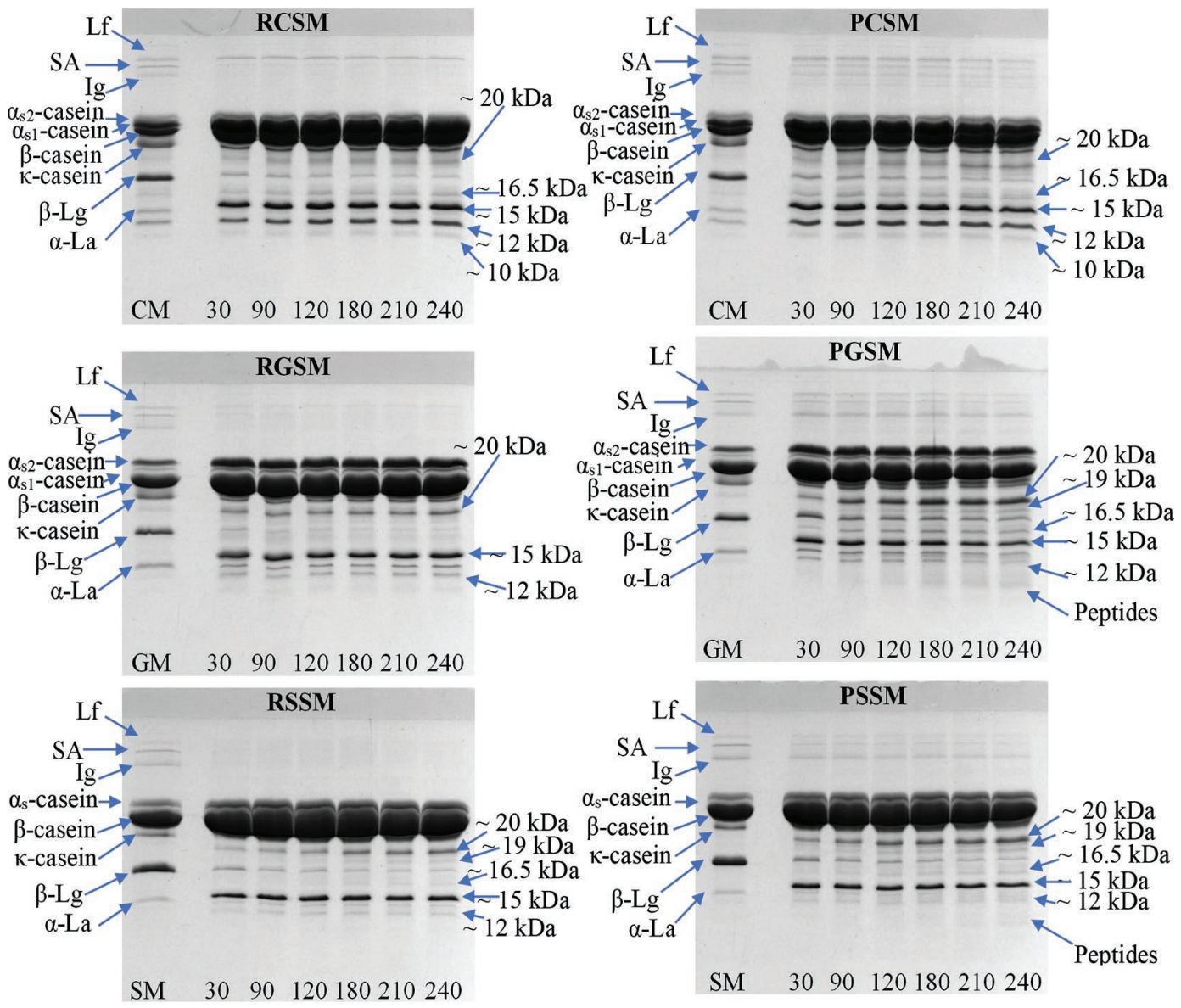

Figure 6. SDS-PAGE patterns of the freeze-dried clots ( $\sim 36 \mathrm{mg}$ of protein in each lane) collected during the gastric digestion of raw and pasteurized skim milk in the human gastric simulator at different times $(30,90,120,180$, 210, and 240 min). RCSM = raw cow skim milk; RGSM = raw goat skim milk; RSSM = raw sheep skim milk; PCSM = pasteurized cow skim milk; PGSM = pasteurized goat skim milk; PSSM = pasteurized sheep skim milk; $\mathrm{CM}=$ cow skim milk; $\mathrm{GM}=$ goat skim milk; $\mathrm{SM}=$ sheep skim milk; Lf = lactoferrin; $\mathrm{SA}=$ serum albumin .

product of the hydrolysis of $\alpha_{S^{-}}$and $\beta$-caseins by the milk proteolytic enzyme plasmin (Bastian and Brown, 1996). Thus, the $\sim 20$ - and $12-\mathrm{kDa}$ bands observed in our study could have been $\gamma$-casein bands. Ye et al. (2016b) also observed the presence of an $\sim 20$-kDa band in cow skim milk clots. The results obtained for the raw cow skim milk clot are in agreement with previous studies on cow skim milk (Miranda and Pelissier, 1983; Ye et al., 2016b).

The protein hydrolysis profile of the raw sheep milk clots showed a pattern very similar to that of the raw cow milk clots, with a few exceptions (Figure 6, RSSM). An $\sim 16.5-\mathrm{kDa}$ band and a new band at $\sim 19 \mathrm{kDa}$ appeared in the sheep milk clots only after 120 min of digestion. Also, the $\sim 10-\mathrm{kDa}$ band that was present in the cow milk clots appeared to be absent from the sheep milk clots. Relatively higher amounts of $\alpha$-lactalbumin were entrapped in the sheep milk clots than in the cow milk clots, as indicated by its band intensities. The protein digestion profile of the raw goat milk clots (Figure 6,
RGSM) also showed a pattern similar to that of the raw cow and sheep milk clots. However, both the $\sim 16.5-\mathrm{kDa}$ band and the $\sim 10-\mathrm{kDa}$ band appeared to be absent from the raw goat milk clots. Also, the $\alpha$-lactalbumin band intensities of the raw goat milk clots appeared to be higher than those of the raw cow and sheep milk clots. In contrast, the $\beta$-lactoglobulin band intensities of the raw goat milk clots were considerably lower than those of the raw cow and sheep milk clots.

The pasteurized milk clots from all species (Figure 6, PCSM, PGSM, and PSSM) followed a trend similar to their respective raw milk clots; however, the intensities of the whey protein bands ( $\beta$-lactoglobulin, lactoferrin, serum albumin, and immunoglobulin) associated with the pasteurized milk clots increased markedly, especially for goat milk and sheep milk. In addition, toward the end of digestion, greater amounts of peptides appeared to be generated by the pasteurized goat milk clots than by the pasteurized sheep and cow milk clots. Also, in the pasteurized goat milk clots, new bands appeared at 

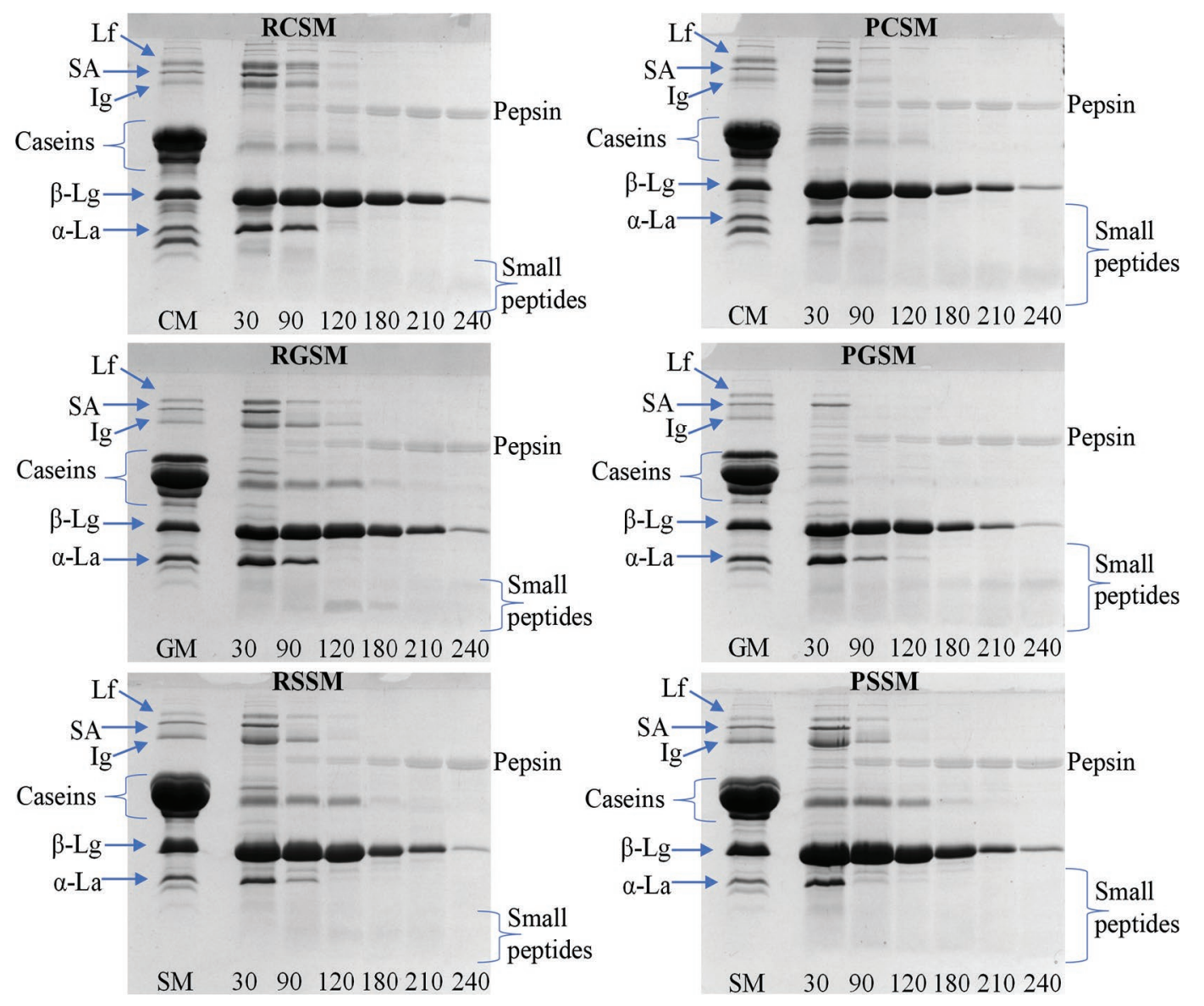

Figure 7. SDS-PAGE patterns of the liquid chyme $(\sim 69 \mu \mathrm{g}$ of protein in each lane) collected during the gastric digestion of raw and pasteurized skim milk in the human gastric simulator at different times $(30,90,120,180,210$, and 240 min). RCSM $=$ raw cow skim milk; RGSM $=$ raw goat skim milk; RSSM = raw sheep skim milk; PCSM = pasteurized cow skim milk; PGSM = pasteurized goat skim milk; PSSM = pasteurized sheep skim milk; $\mathrm{CM}=$ cow skim milk; GM = goat skim milk; $\mathrm{SM}=$ sheep skim milk; Lf = lactoferrin; $\mathrm{SA}=$ serum albumin.

$\sim 19 \mathrm{kDa}$ and $16.5 \mathrm{kDa}$ at $\sim 90$ and 30 min of digestion, respectively, the intensities of which increased thereafter. These bands were absent from the raw goat milk clots. These results indicated that pasteurization may have had a greater effect on the hydrolysis of goat milk proteins than of cow milk proteins.

Figure 7 shows the SDS-PAGE patterns of the protein compositions of the liquid chyme. Analysis of the liquid chyme of raw cow skim milk (Figure 7, RCSM) showed the presence of lactoferrin, serum albumin, immunoglobulins, $\beta$-lactoglobulin, and $\alpha$-lactalbumin at $30 \mathrm{~min}$ of digestion. The intensities of the lactoferrin, serum albumin, immunoglobulin, and $\alpha$-lactalbumin bands decreased rapidly, and these bands disappeared completely within $120 \mathrm{~min}$ of digestion (i.e., $\mathrm{pH}$ $\sim 3.5-4.4$ ). The intensity of the $\beta$-lactoglobulin band decreased gradually with digestion time (especially after 120 min onward), and only a faint $\beta$-lactoglobulin band was present at $240 \mathrm{~min}$. In addition, smaller amounts of caseins were present in the liquid chyme at $30 \mathrm{~min}$, which could have been due to the more open casein network of the clot initially, leading to the delivery of very fine casein particles in the liquid chyme; the intensity of these casein bands decreased rapidly during digestion. Some small peptides were observed at all digestion points in the liquid chyme, which could be the hydrolysis products of both caseins and whey proteins. It should also be noted that the products of casein hydrolysis (those observed in the clots, Figure 6) were not observed in the liquid chyme, which indicated that the hydrolyzed products of the caseins remained bound within the clots (Figures 6 and 7), either via hydrophobic interactions or because of tight physical entrapment within the clot. Similar observations were made for the liquid chyme of the pasteurized cow milk (Figure 7, PCSM).

The SDS-PAGE experiments were run on an equal protein basis at all digestion time points; thus, the dilution of the liquid chyme at different digestion times due to continuous addition of SGF did not affect the results 
for different milks. The disappearance of $\alpha$-lactalbumin within $120 \mathrm{~min}$ ( $\mathrm{pH} \sim 3.5-4.4$ ) of gastric digestion in our study was due to its susceptibility to pepsin hydrolysis below $\mathrm{pH} 4$ because of the change in its protein conformation (Miranda et al., 1989). Native $\beta$-lactoglobulin is considered very resistant to digestion (Reddy et al., 1988; Kitabatake and Kinekawa, 1998) by human gastric enzymes as well as commercial porcine pepsin. Under the conditions of our study, $\beta$-lactoglobulin band intensity began to gradually decrease, especially from 120 min onward (when overall $\mathrm{pH}$ was $<4$ ), indicating its hydrolysis by pepsin. This is in agreement with previous observations of Peram et al. (2013) and Sarkar et al. (2009), who reported that $\sim 20$ to $35 \%$ of native $\beta$-lactoglobulin was hydrolyzed by porcine pepsin after $2 \mathrm{~h}$ of in vitro static incubation at $\mathrm{pH}$ 1.5. They also reported that a higher pepsin-to-substrate ( $\beta$-lactoglobulin) ratio may have been the reason for the observed degradation of native $\beta$-lactoglobulin in their studies.

The protein hydrolysis profiles of the raw and pasteurized goat milk (Figure 7, RGSM and PGSM) and sheep milk (Figure 7, RSSM and PSSM) liquid chyme were observed to be similar to those of the raw and pasteurized cow milk liquid chyme (Figure 7, RCSM and PCSM), despite the differences in protein composition of the different milks. It should be noted that the theoretical pepsin-to-protein concentration used during gastric digestion in this study was kept the same for all milks, considering the differences in their initial protein contents.

\section{Microstructure of the Clots}

The microstructures of the wet clots formed from the raw and pasteurized milk of all species at 15, 90, and 240 min of digestion were observed by confocal scanning laser microscopy (Figures 8 and 9). At 15 min, the protein networks in the clots from the raw milk of all species appeared to be loose with void spaces. These void spaces were filled with liquid entrapped within the protein network. As digestion progressed, the clots became more cohesive and expelled the entrapped liquid; consequently, the protein network became tighter with fewer void spaces (Figure 8). The protein network in the 240-min clot appeared to be smooth, indicating that it was much stronger and more connected toward the end of digestion than at the beginning (at $15 \mathrm{~min}$ ) of digestion. The decrease in the wet weight of the clots observed during the early stages of gastric digestion (Supplemental Figure S3, https://doi.org/10.3168/jds .2020-18779) could be attributed to these changes in the cohesiveness and denseness of the microstructure of the clots (Figures 8 and 9). The microstructural observations further support the results reported for the change in the moisture content of the clots during digestion, which is to say, greater moisture content of the clots at 15 min than at 90 and 240 min, irrespective of the milk species. Although slight apparent differences were detectable in the microstructures of the clots formed from raw cow, goat, and sheep milks, it was not possible to draw any definite conclusions. Ye et al. (2016b) also observed in that the clot from raw cow skim milk had a closely knitted protein network with numerous aqueous pore spaces (at $20 \mathrm{~min}$ ), which, as digestion progressed, became denser and fused into a smooth block with little porosity at a long digestion time (220 $\mathrm{min})$.

The microstructures of the pasteurized milk clots from all species at 15, 90, and 240 min of digestion followed patterns similar to those of the raw milk clots (Figure 9). However, the clots formed by the pasteurized milk at 90 and 240 min of digestion (Figure 9) appeared to have slightly more open protein networks, with a large number of pores, compared with those of raw milk clots (90 and 240 min, Figure 8), especially for goat milk and sheep milk.

\section{Texture Analysis of the Residual Clots}

It should be noted that the texture analysis results are an indicative measurement only, given the heterogeneous and dynamic nature of the clots during gastric digestion. The forces required to penetrate the clots from outside for each species after 240 min of digestion are shown in Figure 10.

No significant differences $(P>0.05)$ were detectable in the mean force required to penetrate the raw goat and sheep skim milk clots from outside, compared with the raw cow skim milk clots. However, a significant difference $(P<0.05)$ was found between the mean forces required to penetrate the raw goat and sheep skim milk clots from outside (Figure 10, OUTSIDE). The mean forces required to penetrate the pasteurized skim milk clots from outside were observed to be significantly lower than those required to penetrate their raw milk counterparts, except for sheep milk, for which the values were lower but not significantly $(P>0.05)$ different (Figure 10, OUTSIDE). In addition, the pasteurized sheep skim milk clots were significantly $(P<$ 0.05 ) firmer than the pasteurized cow and goat skim milk clots, for both of which the firmness was similar (Figure 10, OUTSIDE).

The lower hardness observed for the pasteurized milk clots possibly indicated the slightly more open structure of these clots. Pasteurization $\left(72^{\circ} \mathrm{C}, 15 \mathrm{~s}\right)$ would be expected to cause a small degree of denaturation of whey proteins (Guinee et al., 1998). The denatured 
whey proteins are known to form complexes with the $\kappa$-casein at the casein micelle surface that can interfere with the aggregation of casein micelles during coagulation by chymosin (Kethireddipalli et al., 2010, 2011). This could be a reason for the lower firmness of the pasteurized milk clots observed in our study. Both chymosin and pepsin belong to the same group of aspartic proteinases that hydrolyzes the $\mathrm{Phe}_{105}-\mathrm{Met}_{106}$ bond of $\kappa$-casein and has activity in the $\mathrm{pH}$ range 6 to 7 (Piper and Fenton, 1965; Crabbe, 2004; Moschopoulou, 2011). Because the site of action of both chymosin and pepsin is the same, the mechanism of action of chymosin and pepsin would be expected to be similar in relation to milk clotting.

Another penetration experiment was conducted to analyze the firmness of the inner core of the clots; the clots were cut into 2 halves, and the force required to penetrate the inner core was measured (Figure 10, CORE). The results indicated that the inner cores of the raw and pasteurized sheep skim milk clots were firmer than those of the raw and pasteurized cow (as well as goat) skim milk clots (Figure 10, CORE). It should be

\section{RCSM}
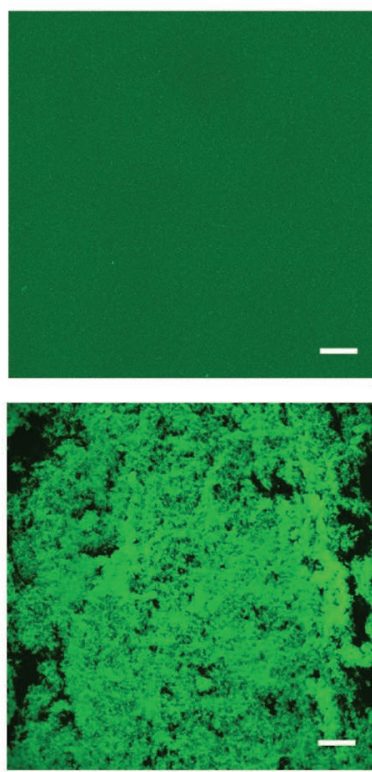

$15 \min$

$90 \mathrm{~min}$
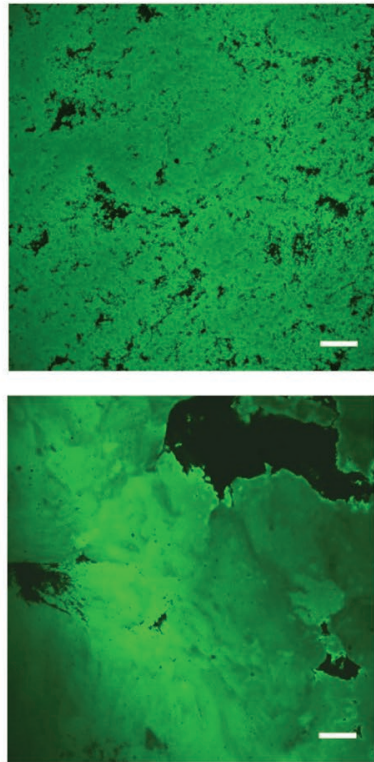

RGSM
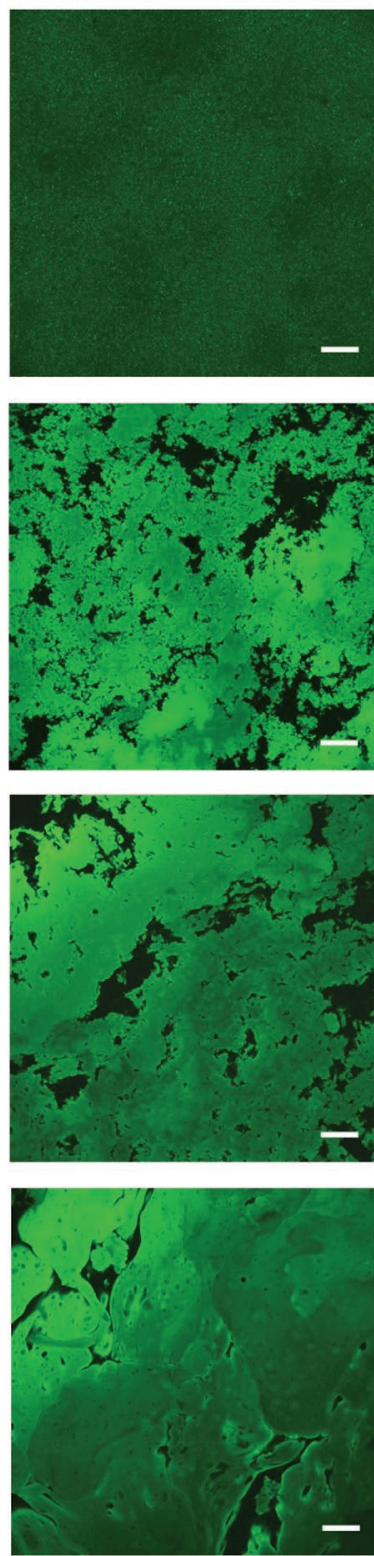

RSSM
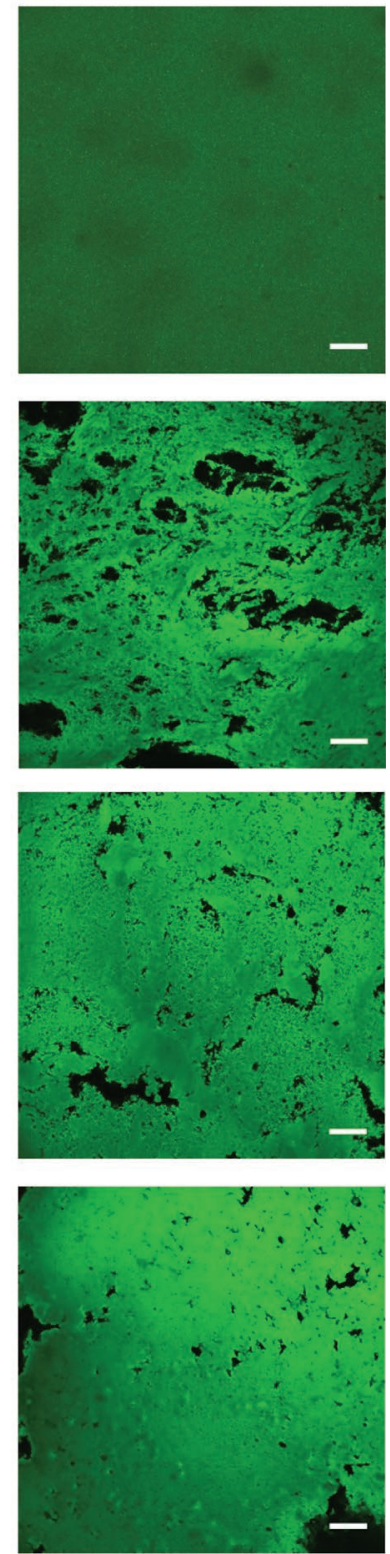

Figure 8. Confocal micrographs of the clots obtained during the gastric digestion of different raw skim milk in the human gastric simulator at different times. RCSM = raw cow skim milk; RGSM = raw goat skim milk; RSSM = raw sheep skim milk. Scale bars represent $25 \mu \mathrm{m}$. 
PCSM
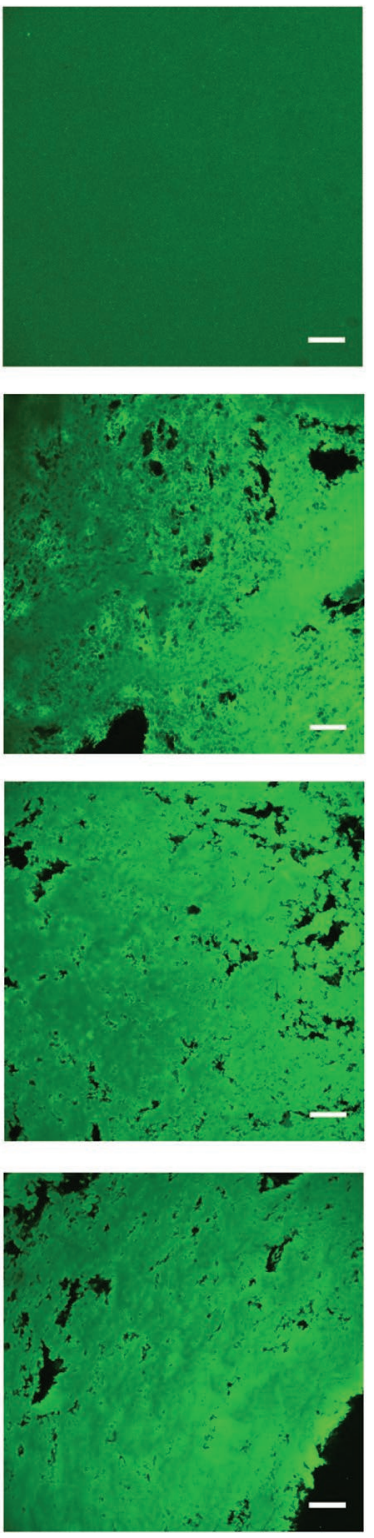

PGSM
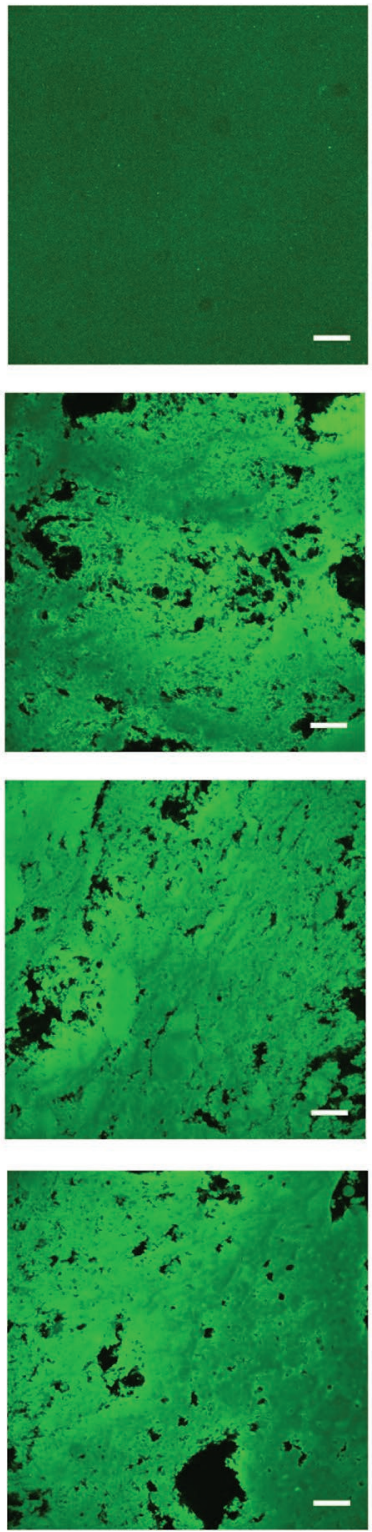

PSSM
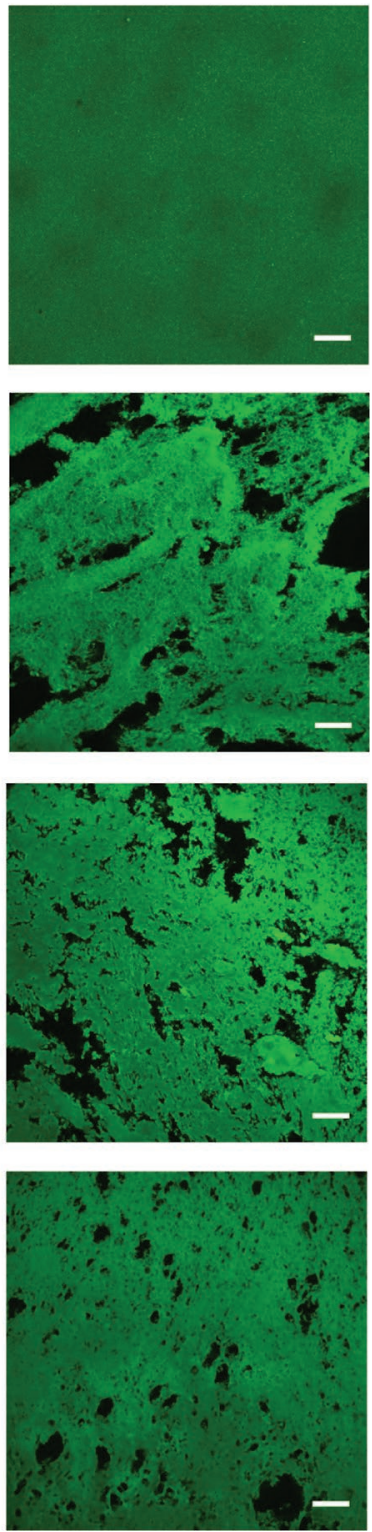

Figure 9. Confocal micrographs of the clots obtained during the gastric digestion of different pasteurized skim milk in the human gastric simulator at different times. PCSM = pasteurized cow skim milk; PGSM = pasteurized goat skim milk; PSSM = pasteurized sheep skim milk. Scale bars represent $25 \mu \mathrm{m}$.

noted that the inner cores (Figure 10, CORE) of the raw and pasteurized milk clots from all species were significantly $(P<0.05)$ firmer than their outside layers (Figure 10, OUTSIDE), except for the pasteurized goat milk clots, for which the force required to penetrate the inside core was not significantly $(P>0.05)$ different from that required to penetrate the outside layers (Figure 10).

The relatively higher firmness observed for the sheep milk clots could have been due to their lower moisture content, as observed earlier (Figure 3, $240 \mathrm{~min}$ ). Sheep milk is also known to form stronger gels (with glucono$\delta$-lactone or enzymes) primarily because of its higher casein content compared with goat milk and cow milk (Storry et al., 1983; Ould Eleya et al., 1998; Roy et al., 2020), which contributes to the formation of a stronger clot by sheep milk in the HGS.

The greater degree of softness of the outside surface of the clot was due to its continuous contact with the surrounding liquid in the HGS and reduced penetration of liquid to the inner core due to its firm texture. This supports the previous findings of Ye et al. (2016b) and 


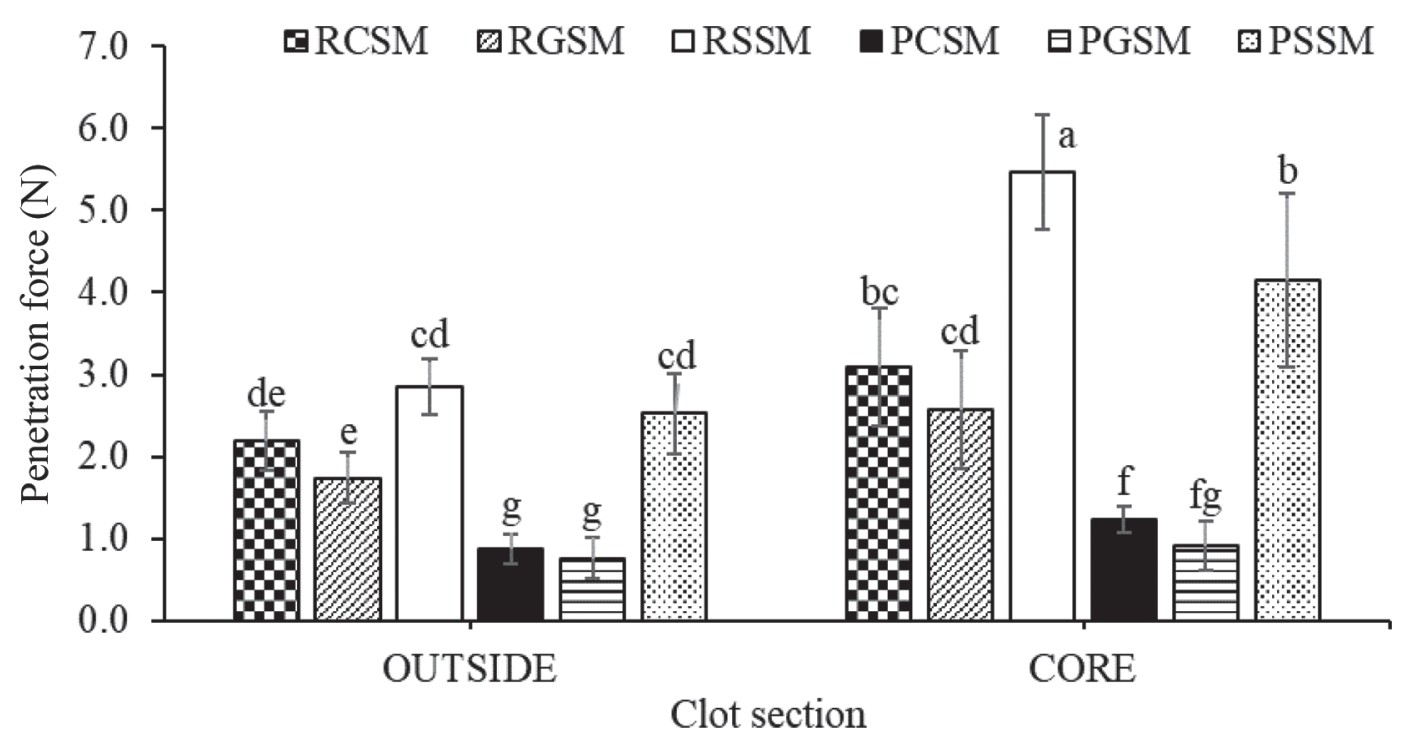

Figure 10. Force $(\mathrm{N})$ required to penetrate the skim milk clots remaining in the human gastric simulator at 240 min. OUTSIDE $=$ measurements taken on complete clot when penetrated from outside; CORE = measurements taken on half-cut clot when penetrated from inside (i.e., at the core). RCSM = raw cow skim milk; RGSM = raw goat skim milk; RSSM = raw sheep skim milk; PCSM = pasteurized cow skim milk; PGSM $=$ pasteurized goat skim milk; PSSM = pasteurized sheep skim milk. Tukey's post hoc pairwise comparison test was performed when milk $\times$ section interaction effect was significant $(P<0.05)$. Different letters $(\mathrm{a}-\mathrm{g})$ above bars indicate significant differences $(P<0.05)$. Each data point represents mean $\pm \mathrm{SD}$ of results from at least 2 different batches of milk.

Mulet-Cabero (2018), who reported that the proteins in the outer layer were hydrolyzed more quickly than the proteins in the inner core of the cow milk clots because of the lower pepsin diffusion to the core (inside) due to the compact and dense nature of the clot.

\section{CONCLUSIONS}

Raw skim milk from cow, goat, and sheep separated into a clot and a liquid phase in the HGS. The amount of the clot formed at the beginning of the gastric digestion was directly proportional to the protein and TS contents of the different skim milks. The macroand microstructures of the clots formed from all skim milks underwent similar dynamic changes throughout digestion. The fundamental insights generated from this study provide an improved understanding of the comparative dynamic gastric digestion of milk from different species. Further studies are necessary to elucidate how the presence of fat globules as well as the application of commercial processing conditions (such as UHT) may affect the gastric digestion of non-cow milk proteins.

\section{ACKNOWLEDGMENTS}

This study was supported by Tertiary Education Commission-Centre of Research Excellence (CoRE) funding, Wellington, New Zealand. The authors ac- knowledge the support of Massey University No. 4 Dairy Farm (Palmerston North, New Zealand), Dairy Goat Co-operative (Hamilton, New Zealand), and Neer Enterprises Limited (Carterton, New Zealand) for supplying the milk. The authors thank Niki Minards and Matthew Savoian of Manawatu Microscopy and Imaging Centre, Palmerston North, New Zealand, for training and providing access to confocal scanning laser microscopy. The authors also thank Anant Dave (Riddet Institute, Massey University, Palmerston North, New Zealand) for insightful discussion while conducting the in vitro digestion experiments. The authors have not stated any conflicts of interest.

\section{REFERENCES}

Agudelo, R. A., S. F. Gauthier, Y. Pouliot, J. Marin, and L. Savoie. 2004. Kinetics of peptide fraction release during in vitro digestion of casein. J. Sci. Food Agric. 84:325-332. https://doi.org/10.1002/ jsfa.1662.

Anema, S. G. 1997. The effect of chymosin on к-casein-coated polystyrene latex particles and bovine casein micelles. Int. Dairy J. 7:553-558. https://doi.org/10.1016/S0958-6946(97)00048-4.

Anema, S. G., and Y. Li. 2003a. Association of denatured whey proteins with casein micelles in heated reconstituted skim milk and its effect on casein micelle size. J. Dairy Res. 70:73-83. https://doi .org/10.1017/S0022029902005903.

Anema, S. G., and Y. Li. 2003b. Effect of pH on the association of denatured whey proteins with casein micelles in heated reconstituted skim milk. J. Agric. Food Chem. 51:1640-1646. https://doi.org/10 $.1021 /$ jf025673a.

AOAC. 2005. Official Methods of Analysis of AOAC International (OMA) online. AOAC International, Rockville, MD. Accessed Mar. 2017. http://www.eoma.aoac.org/Methods/. 
Barłowska, J., M. Szwajkowska, Z. Litwińczuk, and J. Król. 2011. Nutritional value and technological suitability of milk from various animal species used for dairy production. Compr. Rev. Food Sci. Food Saf. 10:291-302. https://doi.org/10.1111/j.1541-4337.2011 .00163.x.

Bastian, E. D., and R. J. Brown. 1996. Plasmin in milk and dairy products: An update. Int. Dairy J. 6:435-457. https://doi.org/10 .1016/0958-6946(95)00021-6.

Bell, A. E., and I. Vlahopouloua. 1995. Preliminary studies on the gelation processes of fermented and GDL-acidified bovine and caprine milk systems. Int. J. Dairy Technol. 48:112-116. https://doi .org/10.1111/j.1471-0307.1995.tb02479.x.

Boirie, Y., M. Dangin, P. Gachon, M. P. Vasson, J. L. Maubois, and B. Beaufrère. 1997. Slow and fast dietary proteins differently modulate postprandial protein accretion. Proc. Natl. Acad. Sci. USA 94:14930-14935. https://doi.org/10.1073/pnas.94.26.14930.

Boutrou, R., C. Gaudichon, D. Dupont, J. Jardin, G. Airinei, A. Marsset-Baglieri, R. Benamouzig, D. Tome, and J. Leonil. 2013. Sequential release of milk protein-derived bioactive peptides in the jejunum in healthy humans. Am. J. Clin. Nutr. 97:1314-1323. https://doi.org/10.3945/ajcn.112.055202.

Chabance, B., P. Marteau, J. Rambaud, D. Migliore-Samour, M. Boynard, P. Perrotin, R. Guillet, P. Jolles, and A. Fiat. 1998. Casein peptide release and passage to the blood in humans during digestion of milk or yogurt. Biochimie 80:155-165. https://doi.org/10 .1016/S0300-9084(98)80022-9.

Claeys, W. L., C. Verraes, S. Cardoen, J. De Block, A. Huyghebaert, K. Raes, K. Dewettinck, and L. Herman. 2014. Consumption of raw or heated milk from different species: an evaluation of the nutritional and potential health benefits. Food Control 42:188-201. https://doi.org/10.1016/j.foodcont.2014.01.045.

Crabbe, M. J. C. 2004. Rennets: General and molecular aspects. Pages 19-45 in Cheese: Chemistry, Physics and Microbiology. Vol. 1. P. F. Fox, P. L. H. McSweeney, T. M. Cogan, and T. P. Guinee, ed. Academic Press, London, UK.

Crowley, S. V., A. L. Kelly, J. A. Lucey, and J. A. O'Mahony. 2017. Potential applications of non-bovine mammalian milk in infant nutrition. Pages 625-654 in Handbook of Milk of Non-Bovine Mammals. John Wiley and Sons Ltd., Oxford, UK.

Dalgleish, D. G. 2014. The basis of structure in dairy-based foods: Casein micelles and their properties. Pages 83-105 in Food Structures, Digestion and Health. Elsevier, London, UK.

Dalgleish, D. G., and A. J. R. Law. 1989. pH-induced dissociation of bovine casein micelles. II. Mineral solubilization and its relation to casein release. J. Dairy Res. 56:727-735. https://doi.org/10.1017/ S0022029900029290.

Domagała, J. 2009. Instrumental texture, syneresis and microstructure of yoghurts prepared from goat, cow and sheep milk. Int. J. Food Prop. 12:605-615. https://doi.org/10.1080/10942910801992934.

El-Agamy, E. I. 2007. The challenge of cow milk protein allergy. Small Rumin. Res. 68:64-72. https://doi.org/10.1016/j.smallrumres 2006.09.016.

Ferrua, M. J., and R. P. Singh. 2015. Human gastric simulator (Riddet model). Pages 61-71 in The Impact of Food Bioactives on Health. Springer, New York, NY.

Grimm, M., M. Koziolek, J.-P. Kühn, and W. Weitschies. 2018. Interindividual and intraindividual variability of fasted state gastric fluid volume and gastric emptying of water. Eur. J. Pharm. Biopharm. 127:309-317. https://doi.org/10.1016/j.ejpb.2018.03.002.

Guinee, T., M. Fenelon, E. Mulholland, B. O'kennedy, N. O'brien, and W. Reville. 1998. The influence of milk pasteurization temperature and $\mathrm{pH}$ at curd milling on the composition, texture and maturation of reduced fat cheddar cheese. Int. J. Dairy Technol. 51:1-10. https://doi.org/10.1111/j.1471-0307.1998.tb02631.x.

Haenlein, G. F. W. 1996. Nutritional value of dairy products of ewe and goat milk. Pages 159-178 in Proc. Int. Dairy Federation: Production and Utilization of Ewe and Goat Milk. IDF National Committees, Brussels, Belgium.

Hodgkinson, A. J., O. A. M. Wallace, I. Boggs, M. Broadhurst, and C. G. Prosser. 2018. Gastric digestion of cow and goat milk: Impact of infant and young child in vitro digestion conditions. Food Chem. 245:275-281. https://doi.org/10.1016/j.foodchem.2017.10.028.

Jasińska, B. 1995. The comparison of pepsin and trypsin action on goat, cow, mare and human caseins. Rocz. Akad. Med. Bialymst. 40:486-493.

Jenness, R. 1980. Composition and characteristics of goat milk: Review 1968-1979. J. Dairy Sci. 63:1605-1630. https://doi.org/10 .3168/jds.S0022-0302(80)83125-0.

Jollès, P. 1966. Progress in the chemistry of casein. Angew. Chem. 5:558-566. https://doi.org/10.1002/anie.196605581.

Kethireddipalli, P., A. R. Hill, and D. G. Dalgleish. 2010. Protein interactions in heat-treated milk and effect on rennet coagulation. Int. Dairy J. 20:838-843. https://doi.org/10.1016/j.idairyj.2010.06 .003 .

Kethireddipalli, P., A. R. Hill, and D. G. Dalgleish. 2011. Interaction between casein micelles and whey protein/k-casein complexes during renneting of heat-treated reconstituted skim milk powder and casein micelle/serum mixtures. J. Agric. Food Chem. 59:14421448. https://doi.org/10.1021/jf103943e.

Kitabatake, N., and Y.-I. Kinekawa. 1998. Digestibility of bovine milk whey protein and $\beta$-lactoglobulin in vitro and in vivo. J. Agric. Food Chem. 46:4917-4923. https://doi.org/10.1021/jf9710903.

Kong, F., and R. P. Singh. 2008. Disintegration of solid foods in human stomach. J. Food Sci. 73:R67-R80. https://doi.org/10.1111/j .1750-3841.2008.00766.x.

Kong, F., and R. P. Singh. 2010. A human gastric simulator (HGS) to study food digestion in human stomach. J. Food Sci. 75:E627E635. https://doi.org/10.1111/j.1750-3841.2010.01856.x.

Li, S., A. Ye, and H. Singh. 2019. Seasonal variations in composition, properties, and heat-induced changes in bovine milk in a seasonal calving system. J. Dairy Sci. 102:7747-7759. https://doi.org/10 .3168/jds.2019-16685.

Maathuis, A., R. Havenaar, T. He, and S. Bellmann. 2017. Protein digestion and quality of goat and cow milk infant formula and human milk under simulated infant conditions. J. Pediatr. Gastroenterol. Nutr. 65:661-666. https://doi.org/10.1097/MPG .0000000000001740 .

Mahé, S., N. Roos, R. Benamouzig, L. Davin, C. Luengo, L. Gagnon, N. Gausserges, J. Rautureau, and D. Tomé. 1996. Gastrojejunal kinetics and the digestion of $[15 \mathrm{~N}] \beta$-lactoglobulin and casein in humans: the influence of the nature and quantity of the protein. Am. J. Clin. Nutr. 63:546-552. https://doi.org/10.1093/ajcn/63 .4 .546 .

Maltby, J. R., A. Sutherland, J. Sale, and E. Shaffer. 1986. Preoperative oral fluids: Is a five-hour fast justified prior to elective surgery? Anesth. Analg. 65:1112-1116. https://doi.org/10.1213/ 00000539-198611000-00003.

Minekus, M., M. Alminger, P. Alvito, S. Ballance, T. Bohn, C. Bourlieu, F. Carriere, R. Boutrou, M. Corredig, D. Dupont, C. Dufour L. Egger, M. Golding, S. Karakaya, B. Kirkhus, S. Le Feunteun, U. Lesmes, A. Macierzanka, A. Mackie, S. Marze, D. J. McClements, O. Ménard, I. Recio, C. N. Santos, R. P. Singh, G. E. Vegarud, M. S. J. Wickham, W. Weitschies, and A. Brodkorb. 2014. A standardised static in vitro digestion method suitable for food-An international consensus. Food Funct. 5:1113-1124. https://doi.org/ 10.1039/C3FO60702J.

Miranda, G., G. Hazé, P. Scanff, and J. Pélissier. 1989. Hydrolysis of $\alpha$-lactalbumin by chymosin and pepsin. Effect of conformation and pH. Lait 69:451-459. https://doi.org/10.1051/lait:1989630.

Miranda, G., and J.-P. Pelissier. 1983. Kinetic studies of in vivo digestion of bovine unheated skim-milk proteins in the rat stomach. J. Dairy Res. 50:27-36. https://doi.org/10.1017/S0022029900032490.

Moschopoulou, E. 2011. Characteristics of rennet and other enzymes from small ruminants used in cheese production. Small Rumin. Res. 101:188-195. https://doi.org/10.1016/j.smallrumres.2011.09 .039 .

Mulet-Cabero, A.-I. 2018. Effect of dairy structures on gastric behaviour and nutrient digestion kinetics using a semi-dynamic model. $\mathrm{PhD}$ Thesis. Quadram Institute Bioscience, University of East Anglia, Norwich, UK. 
Mulet-Cabero, A.-I., A. R. Mackie, A. Brodkorb, and P. J. Wilde. 2020. Dairy structures and physiological responses: A matter of gastric digestion. Crit. Rev. Food Sci. Nutr. 1-16. https://doi.org/ 10.1080/10408398.2019.1707159.

Mulet-Cabero, A.-I., A. R. Mackie, P. J. Wilde, M. A. Fenelon, and A. Brodkorb. 2019. Structural mechanism and kinetics of in vitro gastric digestion are affected by process-induced changes in bovine milk. Food Hydrocoll. 86:172-183. https://doi.org/10.1016/ j.foodhyd.2018.03.035.

Nguyen, H. T. H., S. Afsar, and L. Day. 2018. Differences in the microstructure and rheological properties of low-fat yoghurts from goat, sheep and cow milk. Food Res. Int. 108:423-429. https://doi.org/ 10.1016/j.foodres.2018.03.040.

Ould Eleya, M. M., S. Desobry Banon, N. Vetier, and J. Hardy. 1998. Rheological study of acid gels from cow, goat and sheep milks. Dairy Sci. Technol. 78:453-459.

Park, Y. W. 1991. Relative buffering capacity of goat milk, cow milk, soy-based infant formulas, and commercial nonprescription antacid drugs. J. Dairy Sci. 74:3326-3333. https://doi.org/10.3168/ jds.S0022-0302(91)78520-2.

Park, Y. W. 2007. Rheological characteristics of goat and sheep milk. Small Rumin. Res. 68:73-87. https://doi.org/10.1016/j .smallrumres.2006.09.015.

Park, Y. W., M. Juarez, M. Ramos, and G. F. W. Haenlein. 2007. Physico-chemical characteristics of goat and sheep milk. Small Rumin. Res. 68:88-113. https://doi.org/10.1016/j.smallrumres.2006 .09.013.

Pellegrini, O., F. Remeuf, and M. Rivemale. 1994. Évolution des caractéristiques physico-chimiques et des paramètres de coagulation du lait de brebis collecté dans la région de Roquefort. Lait 74:425442. https://doi.org/10.1051/lait:1994635.

Peram, M. R., S. M. Loveday, A. Ye, and H. Singh. 2013. In vitro gastric digestion of heat-induced aggregates of $\beta$-lactoglobulin. J. Dairy Sci. 96:63-74. https://doi.org/10.3168/jds.2012-5896.

Piper, D. W., and B. H. Fenton. 1965. pH stability and activity curves of pepsin with special reference to their clinical importance. Gut 6:506-508. https://doi.org/10.1136/gut.6.5.506.

Reddy, I. M., N. K. Kella, and J. E. Kinsella. 1988. Structural and conformational basis of the resistance of beta-lactoglobulin to peptic and chymotryptic digestion. J. Agric. Food Chem. 36:737-741. https://doi.org/10.1021/jf00082a015.

Remeuf, F., and J. Lenoir. 1986. Relationship between the physicochemical characteristics of goat's milk and its rennetability. Bulletin-Fédération Internationale de Laiterie 202:68-72.

Remeuf, F., J. Lenoir, C. Duby, M.-T. Letilly, and A. Normand. 1989. Etude des relations entre les caractéristiques physico-chimiques des laits de chèvre et leur aptitude à la coagulation par la présure. Lait 69:499-518. https://doi.org/10.1051/lait:1989634.

Roy, D., A. Ye, P. J. Moughan, and H. Singh. 2020. Gelation of milks of different species (dairy cattle, goat, sheep, red deer, and water buffalo) using glucono- $\delta$-lactone and pepsin. J. Dairy Sci. 103:5844-5862. https://doi.org/10.3168/jds.2019-17571.

Rynne, N. M., T. P. Beresford, A. L. Kelly, and T. P. Guinee. 2004. Effect of milk pasteurization temperature and in situ whey protein denaturation on the composition, texture and heat-induced functionality of half-fat Cheddar cheese. Int. Dairy J. 14:989-1001. https://doi.org/10.1016/j.idairyj.2004.03.010.

Salaün, F., B. Mietton, and F. Gaucheron. 2005. Buffering capacity of dairy products. Int. Dairy J. 15:95-109. https://doi.org/10.1016/ j.idairyj.2004.06.007.
Sarkar, A., K. K. T. Goh, R. P. Singh, and H. Singh. 2009. Behaviour of an oil-in-water emulsion stabilized by $\beta$-lactoglobulin in an in vitro gastric model. Food Hydrocoll. 23:1563-1569. https://doi.org/ 10.1016/j.foodhyd.2008.10.014.

Sood, S. M., D. K. Gaind, and R. K. Dewan. 1979. Correlation between micelle salvation and calcium content. N. Z. J. Dairy Sci. Technol. 14:32-44.

Stergiadis, S., N. P. Nørskov, S. Purup, I. Givens, and M. R. Lee. 2019. Comparative nutrient profiling of retail goat and cow milk. Nutrients 11:2282. https://doi.org/10.3390/nu11102282.

Storry, J. E., A. S. Grandison, D. Millard, A. J. Owen, and G. D. Ford. 1983. Chemical composition and coagulating properties of renneted milks from different breeds and species of ruminant. J. Dairy Res. 50:215-229. https://doi.org/10.1017/S0022029900023025.

Tam, J. J., and J. R. Whitaker. 1972. Rates and extents of hydrolysis of several caseins by pepsin, rennin, Endothia parasitica protease and Mucor pusillus protease. J. Dairy Sci. 55:1523-1531. https:// doi.org/10.3168/jds.S0022-0302(72)85714-X.

Vithana, N. L. O. 2012. A comparative study of immunomodulatory activity of deer and cow milk proteins. PhD Thesis. Food Science, Lincoln University, Christchurch, New Zealand.

Wang, X., A. Ye, Q. Lin, J. Han, and H. Singh. 2018. Gastric digestion of milk protein ingredients: Study using an in vitro dynamic model. J. Dairy Sci. 101:6842-6852. https://doi.org/10.3168/jds .2017-14284.

Wisén, O., and C. Johansson. 1992. Gastrointestinal function in obesity: Motility, secretion, and absorption following a liquid test meal. Metabolism 41:390-395. https://doi.org/10.1016/0026 -0495(92)90073-J.

Ye, A., J. Cui, D. Dalgleish, and H. Singh. 2016a. The formation and breakdown of structured clots from whole milk during gastric digestion. Food Funct. 7:4259-4266. https://doi.org/10.1039/ C6FO00228E

Ye, A., J. Cui, D. Dalgleish, and H. Singh. 2016b. Formation of a structured clot during the gastric digestion of milk: Impact on the rate of protein hydrolysis. Food Hydrocoll. 52:478-486. https://doi .org/10.1016/j.foodhyd.2015.07.023.

Ye, A., J. Cui, D. Dalgleish, and H. Singh. 2017. Effect of homogenization and heat treatment on the behavior of protein and fat globules during gastric digestion of milk. J. Dairy Sci. 100:36-47. https://doi.org/10.3168/jds.2016-11764.

Ye, A., W. Liu, J. Cui, X. Kong, D. Roy, Y. Kong, J. Han, and H. Singh. 2019. Coagulation behaviour of milk under gastric digestion: Effect of pasteurization and ultra-high temperature treatment. Food Chem. 286:216-225. https://doi.org/10.1016/j .foodchem.2019.02.010.

\section{ORCIDS}

Debashree Roy @ https://orcid.org/0000-0002-8643-7566 Aiqian Ye @ https://orcid.org/0000-0003-1048-8858

Paul J. Moughan ( https://orcid.org/0000-0001-9644-9133 Harjinder Singh ๑ https://orcid.org/0000-0002-8807-3241 